\title{
REVIEW ARTICLE OPEN Corrosion of metallic materials fabricated by selective laser melting
}

\author{
Decheng Kong ${ }^{1}$, Chaofang Dong ${ }^{1}$, Xiaoqing $\mathrm{Ni}^{2}$ and Xiaogang $\mathrm{Li}^{1}$
}

Additive manufacturing is an emerging technology that challenges traditional manufacturing methods. However, the corrosion behaviour of additively manufactured parts must be considered if additive techniques are to find widespread application. In this paper, we review relationships between the unique microstructures and the corresponding corrosion behaviour of several metallic alloys fabricated by selective laser melting, one of the most popular powder-bed additive technologies for metals and alloys. Common issues related to corrosion in selective laser melted parts, such as pores, molten pool boundaries, surface roughness and anisotropy, are discussed. Widely printed alloys, including Ti-based, Al-based and Fe-based alloys, are selected to illustrate these relationships, and the corrosion properties of alloys produced by selective laser melting are summarised and compared to their conventionally processed counterparts.

npj Materials Degradation (2019)3:24; https://doi.org/10.1038/s41529-019-0086-1

\section{INTRODUCTION}

Additive manufacturing (AM) is a key emerging technology that is challenging multiple manufacturing methods, and the principle of $\mathrm{AM}$ is the layer-by-layer addition of powders or liquids to fabricate an object. ${ }^{1,2}$ To date, there are many metallic materials that can be printed effectively, and the existing AM technologies are divided into two main categories: powder-fed and powder-bed systems. The powder-fed category is further classified for direct laser deposition (DLD), laser engineered net shaping methods and so on, ${ }^{3-8}$ while the powder-bed category involves selective laser melting (SLM), selective laser sintering and electron beam melting technologies. ${ }^{9-14}$ In general, the cooling rate for SLM is usually $>10^{5} \mathrm{~K} / \mathrm{s}$, which is higher than that of DLD (ranging from $10^{3}$ to $10^{5} \mathrm{~K} / \mathrm{s}$ ) and much higher than that for traditional casting methods that have an approximate solidification rate of $273-373 \mathrm{~K} / \mathrm{s} .^{15-18}$

Huge effects have been paid over the past decades in the optimisation of printing devices, including highly reliable laser, inexpensive high-performance computing hardware and software. Currently, SLM has been highlighted for its unique advantages in producing metallic materials in comparison with other fabrication techniques. ${ }^{19-22}$ SLM was developed in $2002^{23}$ and this laser melting technique was originally used as a surface technology to enhance the mechanical properties and corrosion resistance of components. $^{24-28}$ The powder-bed technique has shown the admirable capacity to produce components with high accuracy, required material selection and excellent mechanical properties. ${ }^{29-31}$ The SLM system utilises a focused laser beam, usually a Yb: YAG fibre laser, to melt the powder bed, and the powder is fed from a supply container as displayed in Fig. $1 a^{32-34}$ The laser scan way is designed according to a computer-generated path and the printing process is repeated layer-by-layer by lowering the platform until the whole objects are totally fabricated and then the excessive powder is collected for recycling. There are many factors that will affect the quality of the SLMed parts, including the laser power, scanning speed, powder size, powder type (argon- or nitrogen-atomised), powder layer thickness, scanning path, hatch space, etc., as shown in Fig. 1b. During the SLM process, the local rapid heating and fast cooling rates coupled with thermal cycling induce the formation of unique microstructures with refined grain structures, dislocation cells and internal residual stresses. ${ }^{35}$ These conditions also cause the formation of metallurgical defects, including un-melted powders, micro-cracks, entrapped gas pores, balling, and the rough surfaces, as displayed in Fig. 1c. ${ }^{36-41}$

At present, only AISi10Mg, TiAl6V4 and CoCr alloys, can be reliably printed, ${ }^{42-44}$ whereas Fe-based and Ni-based alloys have been fabricated by SLM recently. ${ }^{45-49}$ The quality of the printed parts from the SLM process is the most challenging issue to be resolved, and there may be multiple factors for this: (1) the rapid cooling rate during solidification results in the formation of nonequilibrium phases with a large range of compositions ${ }^{50-52}$; (2) the molten pool boundary inside the parts, as well as the pores, cracks and rough surfaces, can lead to a severe drop in plasticity. These sites could also be preferential areas for corrosion. ${ }^{53,54}$ Therefore, researchers are acquiring comprehensive data regarding processing parameters and the corresponding printed materials. The effects of the printing parameters on the microstructure and defect evolution during rapid solidification are widely reported, and the optimised printing parameters can usually lead to better mechanical properties. ${ }^{55-57}$ However, the corrosion behaviour and durability of the selective laser melted (SLMed) parts have not drawn considerable attention to date yet ${ }^{58-62}$ and the understanding of the underlying corrosion mechanisms of the SLMed metals and alloys still remains in its infancy. It is well acknowledged that corrosion leads to an annual financial loss of US\$4 trillion globally due to corrosion damage and corrosion protection

\footnotetext{
${ }^{1}$ Beijing Advanced Innovation Center for Materials Genome Engineering, Key Laboratory for Corrosion and Protection (MOE), Institute for Advanced Materials and Technology, University of Science and Technology Beijing, 100083 Beijing, China and ${ }^{2}$ Shanghai Engineering Research Center of 3D Printing Materials, Shanghai Research Institute of Materials, 200437 Shanghai, China

Correspondence: Chaofang Dong (cfdong@ustb.edu.cn) or Xiaogang Li (lixiaogang@ustb.edu.cn)
}

Received: 21 November 2018 Accepted: 15 May 2019

Published online: 11 June 2019 

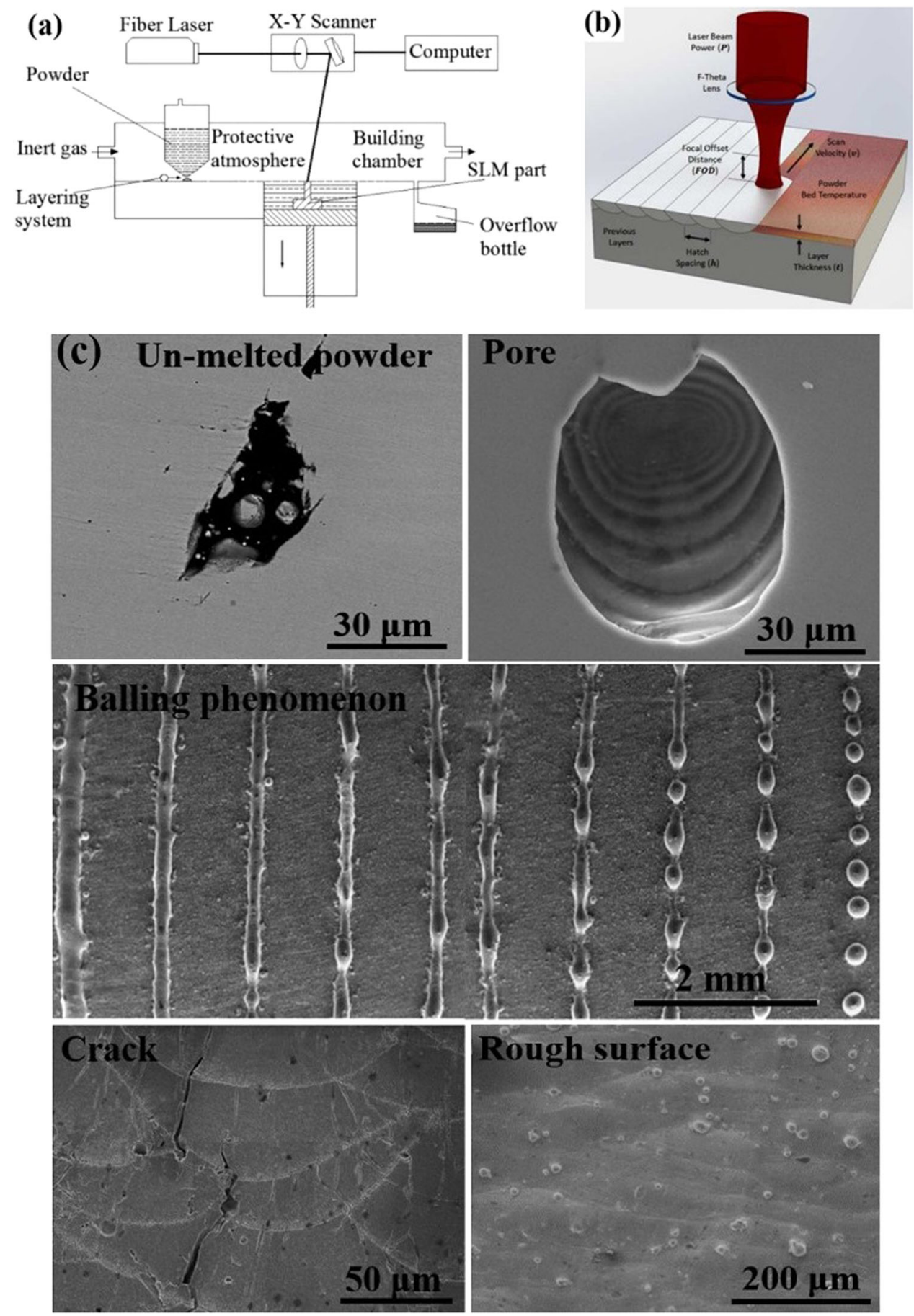

Fig. 1 a Schematic diagram of the SLM system, b scanning strategy of a powder bed under laser irradiation, ${ }^{32-34}$ and $\mathbf{c}$ metallurgical defects in the SLMed parts, including un-melted powder, ${ }^{36}$ entrapped gas pore, ${ }^{37}$ balling phenomenon, ${ }^{38}$ micro-cracks ${ }^{39}$ and rough surfaces. ${ }^{40}$ (a adapted with permission from ref. ${ }^{32}$, copyright Elsevier 2006) (b adapted with permission from ref. ${ }^{34}$, copyright Elsevier 2018) (c adapted with permission from refs. ${ }^{36,37,40}$, copyright Elsevier 2018; ${ }^{38}$ copyright Springer 2011;39 ${ }^{39}$ copyright Springer 2017

investment. $^{63,64}$ Thus, corrosion must be considered with regard to the service life of additive manufactured parts for the widespread application of this technology.

In this paper, we present a brief review of the published literature regarding a number of metallic alloys fabricated via SLM technology, combined with our recent work, to clarify the difference in corrosion behaviour between traditional manufacturing and the novel AM technique.

\section{COMMON CORROSION ISSUES FOR THREE-DIMENSIONAL (3D) PRINTED MATERIALS}

Pores

Pores first appear in powder metallurgy processes and also occur in the SLMed parts, which can affect the corrosion behaviour of the components. ${ }^{65}$ Pores in stainless steels manufactured by powder metallurgy have been confirmed to reduce the passive property in the presence of sulphuric and phosphoric acid 
solutions ${ }^{66}$ and this may also be the case for the SLMed stainless steels. Typically, the pores in the SLMed parts are divided into two types: one type exists around the un-melted powders, and another is caused by the trapped gas inside the powders during gas atomisation. ${ }^{67,68}$ The porosity can be reduced to a certain extent by optimising the printing conditions, including the laser energy, scanning rate and scanning direction. Sander et al. ${ }^{69}$ found that increasing the laser power or decreasing the scanning rate properly can reduce the porosity of the SLMed $316 \mathrm{~L}$ stainless steel. A similar tendency was also obtained for the other metals, such as nickel-based and aluminium-based alloys. ${ }^{70,71}$ A more quantitative way to assess the effect of printing parameters on porosity within components is using the volumetric energy density $\left(E_{\mathrm{v}}\right)$ calculated via Eq. (1), which describes the average energy per volume of powders ${ }^{72,73}$ :

$E_{\mathrm{v}}=\frac{e}{r d t}$

where $e$ is the value of laser energy, $r$ is the scanning rate, $d$ is the hatch distance and $t$ is the thickness of the powder layer. Han et al. ${ }^{74}$ defined the process windows of 120 to $202 \mathrm{~J} / \mathrm{mm}^{3}$ to build Ti6Al4V parts with a porosity $<0.1 \%$. The laser energy density for the lowest porosity $(\sim 0.3 \%)$ of the SLMed $316 \mathrm{~L}$ stainless steel was around $105 \mathrm{~J} / \mathrm{mm}^{3}$ in Fig. $2 \mathrm{a}^{75}$; for the SLMed AZ91D magnesium alloy, the process window for the highest relative density was in the range from 83 to $167 \mathrm{~J} / \mathrm{mm}^{3,76}$; the laser energy density for the lowest porosity (around $0.8 \%$ ) of the SLMed CoCrFeNiMn highentropy alloy was $\sim 60 \mathrm{~J} / \mathrm{mm}^{3}$ in Fig. $2 b^{77}$; while the laser energy density for the lowest porosity (around 3.0\%) of the SLMed Al-12Si alloy was around $30 \mathrm{~J} / \mathrm{mm} .{ }^{3,78}$ However, several authors doubted the availability of the energy density as an assessment criteria of the porosity, and they pointed out that some other printing parameters, such as hatch style and laser diameter, were disregarded, which can also affect the porosity. ${ }^{79}$ Further investigations should be conducted systematically to clarify the relationship between the porosity and processing parameters.

Pores can somewhat compromise the pitting corrosion resistance of the matrix, and an immersion test for the SLMed 304L and 316 stainless steels in ferric chloride solutions showed that the main corrosion attack occurred within the pores. ${ }^{65}$ The authors ascribed this preferential corrosion to local acidification inside the pores, leading to de-passivation of the stainless steel substrate and this process was accelerated by the cathodic activity outside the pores. ${ }^{80}$ Moreover, Schaller et al. ${ }^{81}$ used a microelectrochemical test and noted that a reduced pitting corrosion resistance of the SLMed 17-4 PH stainless steel occurred at pores with diameters that were larger than $50 \mu \mathrm{m}$, whereas a passive condition still occurred when the pore size was smaller than $10 \mu \mathrm{m}$.

Pores with diameters below $10 \mu \mathrm{m}$ in the SLMed $316 \mathrm{~L}$ stainless steel were still corroded in more aggressive environments, such as high-temperature sulphuric acid. ${ }^{82}$ Pore geometry also had a substantial effect on the pitting corrosion behaviours and irregularly shaped pores were deemed to corrode easily due to the enrichment of aggressive ions at the corners. However, the size distribution of the pores in the SLMed parts has not been evaluated systematically in the existing literature and further understanding of the effect of porosity, such as pore size and aspect ratio, on the degradation behaviours of the SLMed parts needs to be clarified. Moreover, the post heat isostatic pressing for the SLMed parts can usually remove pores, and the related effects on corrosion properties are complex and were not discussed in this study. Adding some minor alloying elements to enhance the interfacial bonding force is another method to reduce the porosity in the SLMed parts, such as secondary particulates to produce crack-free high-strength aluminium alloys. ${ }^{39}$ Yusuf et al. ${ }^{83}$ also adopted high-pressure torsion plastic deformation to reduce the porosity, and continued efforts in this regard are needed in the future.

Molten pool boundaries (MPBs)

MPBs are widely present in the SLMed alloys and several authors ${ }^{84,85}$ have noted that elemental segregation, thermal stress and non-equilibrium phases can exist at the MPBs. Actually, the MPBs can be divided into two categories: layer-layer MPB and track-track MPB, as displayed in Fig. 3a. ${ }^{53}$ Two ends of the track-track MPBs connect with layer-layer MPBs, resulting in sharp angles between the two types of MPBs, and these sharp angles would greatly affect the mechanical properties, especially the plasticity. ${ }^{53,54}$

As a non-equilibrium region, selective penetrating attack might occur at the MPB sites preferentially. For the SLMed AISi10Mg alloy, isolated silicon particles can gather inside the melt pool borders. ${ }^{86-88}$ It is well-recognised that silicon is cathodic with respect to the aluminium matrix, which may lead to the formation of micro-galvanic couples, resulting in localised corrosion phenomena. ${ }^{89,90}$ Meanwhile, the corrosion rate of $\mathrm{Al}-\mathrm{Si}$ alloys was verified to increase with increasing silicon content in a $0.5 \mathrm{M} \mathrm{NaCl}$ solution at $25^{\circ} \mathrm{C} .{ }^{91}$ Thus, this unique microstructure caused a selective attack to occur along a preferential path at the MPBs for the SLMed AlSi10Mg alloy as displayed in Fig. 3c. However, this composition segregation phenomenon at the MPBs was not obvious for Fe-based alloys, such as $316 \mathrm{~L}$ stainless steel, but those sites were still preferentially corroded compared with the wrought counterpart as shown in Fig. 3d, e, which should be attributed to the large interfacial stress and micro-voids at the MPBs. ${ }^{92,93}$

\section{Surface roughness}

The surface roughness of the parts fabricated by SLM is usually higher (range from $10 \mu \mathrm{m}$ to $30 \mu \mathrm{m}$ ) than that in parts manufactured by other methods, such as milling $(\sim 1 \mu \mathrm{m}))^{94}$ There are two main reasons for the rough surface in the SLM process, one is caused by evaporation and the Marangoni force existed during the powder melting. The gas expansion destabilises the melt flow, and a highly irregular and unstable melt pool increases the surface roughness and porosity. ${ }^{95-99}$ With thick powder layers, more powder materials are melted by the laser beam and more gas expansion occurs. ${ }^{96,100-102}$ Thus, the surface roughness could be decreased to some extent with a small layer thickness, as displayed in Fig. 4a. However, it is time-consuming to finish a component comprising thin layers. A second reason for the rough surface is improper powder melting and the balling phenomenon (the formation of metallic droplets in opposition to a desired uniform spread of liquid metal on the molten surface during laser melting). ${ }^{103,104}$ When a low laser power is setup, the delivered energy is insufficient to melt the powder particles completely and the solid powder particles adhere to the surface of the component. Therefore, it is expected that surface roughness can be minimised with an increase in the heat input, because a higher heat input value can flatten the melt pool, improving the interlayer connection due to the keyhole effect and increasing the wettability of the melt, as displayed in Fig. $4 \mathrm{~b} .^{105}$ Improved wettability can reduce the melt pool tendency to undergo balling by relieving surface tension variations, thus reducing the roughness. ${ }^{106}$ However, a very high heat input can be detrimental to the surface finish due to the increasing recoil pressure that disrupts the molten pool surface. ${ }^{107}$ Finally, large powders (larger than $100 \mu \mathrm{m})$ are difficult to melt due to the relatively small laser spot diameter (usually range from 50 to $100 \mu \mathrm{m}^{108,109}$ ), which might lead to poor surface finish, as shown in Fig. $4 c^{35}$

Generally, surface conditions play an important role on the corrosion properties of materials involving interfacial reactions with the environment. Pitting susceptibility ${ }^{110}$ and general corrosion rate ${ }^{111}$ all increased with the increase in the surface 
(a)

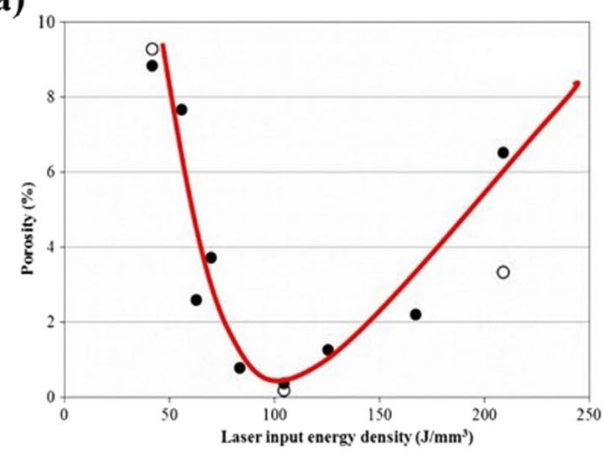

(b)

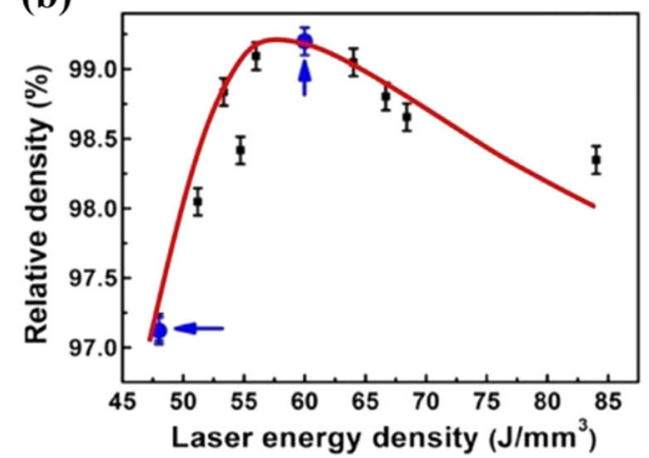

Fig. 2 a porosity of the SLMed $316 \mathrm{~L}$ stainless steel at various energy densities ${ }^{75}$ and $\mathbf{b}$ relative densities of the SLMed CoCrFeNiMn highentropy alloy at various energy densities. ${ }^{77}$ (a adapted with permission from ref. ${ }^{75}$, copyright Springer 2017) (b adapted with permission from ref. ${ }^{77}$, copyright Elsevier 2018)

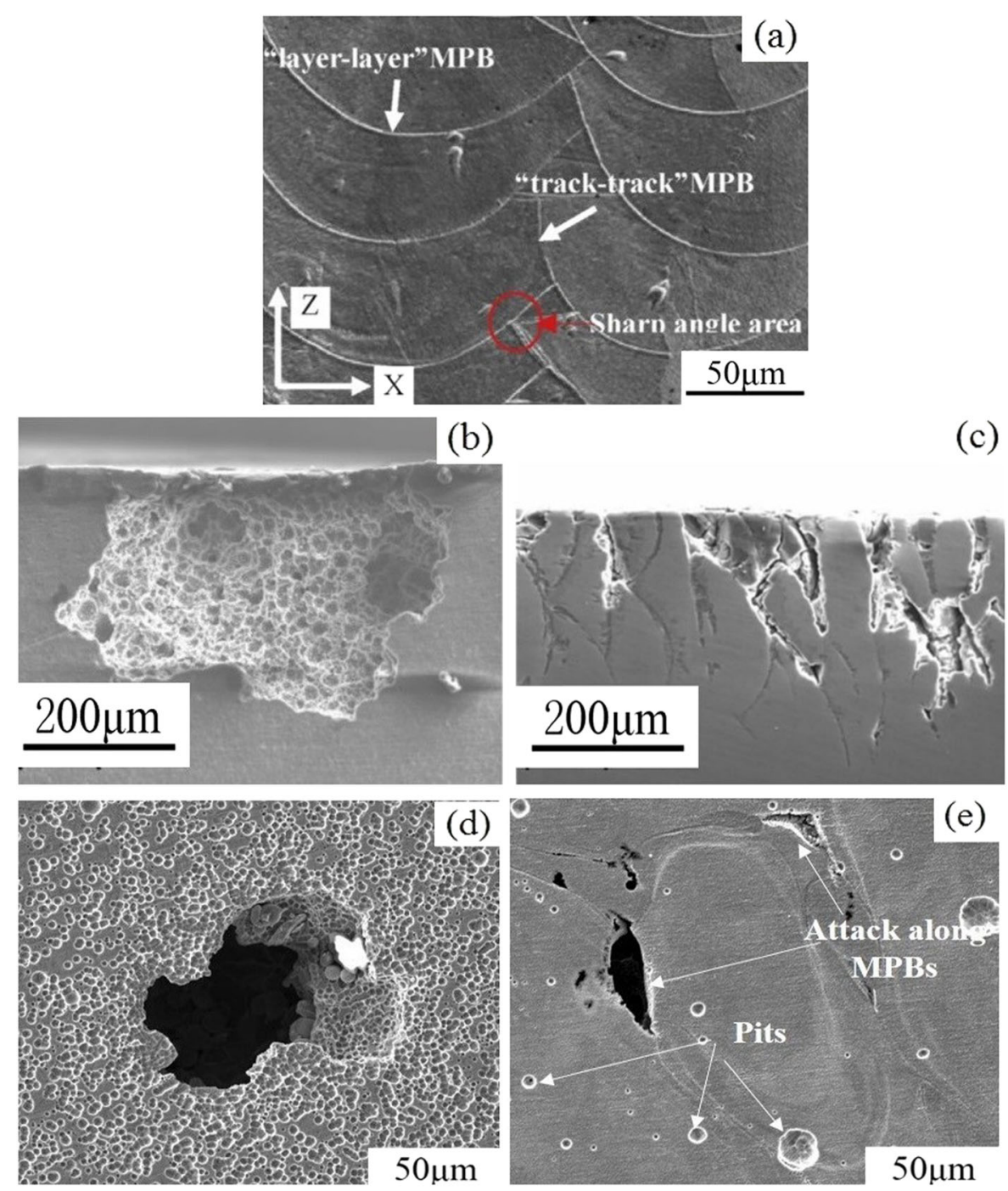

Fig. 3 a Scanning electron morphology of the MPBs in a SLMed sample, ${ }^{53}$ cross-sectional corroded morphologies of $\mathbf{b}$ wrought and $\mathbf{c}$ SLMed AlSi10Mg alloy in NaCl solution, ${ }^{206}$ surface corroded morphologies of $\mathbf{d}$ wrought and e SLMed $316 \mathrm{~L}$ stainless steel in ferric chloride solution. ${ }^{92}$ (a adapted with permission from ref. ${ }^{53}$, copyright Elsevier 2014) (b and c adapted with permission from ref. ${ }^{206}$, copyright Elsevier 2016$)(\mathbf{d}$ and e adapted with permission from ref. ${ }^{92}$, copyright Springer 2019) 
(a)

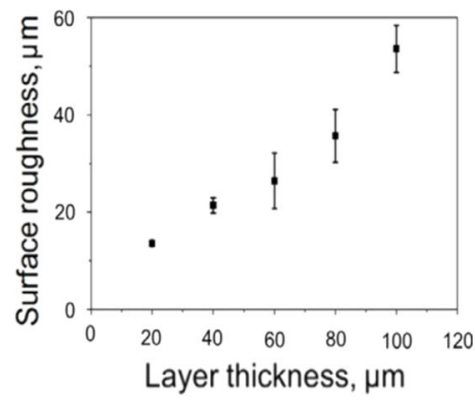

(b)

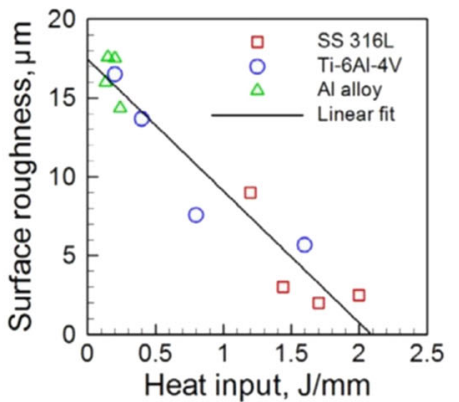

(c)

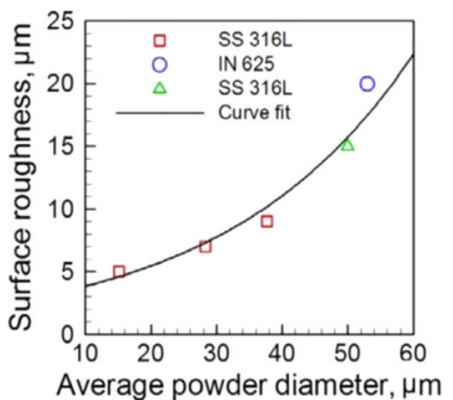

Fig. 4 Relationship between surface roughness and a layer thickness, ${ }^{100} \mathbf{b}$ heat input ${ }^{105}$ and $\mathbf{c}$ powder diameter. ${ }^{35}$ (a adapted with permission from ref. ${ }^{100}$, https://doi.org/10.1016/j.actamat.2015.06.004, Creative Commons Attribution License) (b adapted with permission from ref. ${ }^{105}$, copyright Springer 2012) (c adapted with permission from ref. ${ }^{35}$, copyright Elsevier 2017)
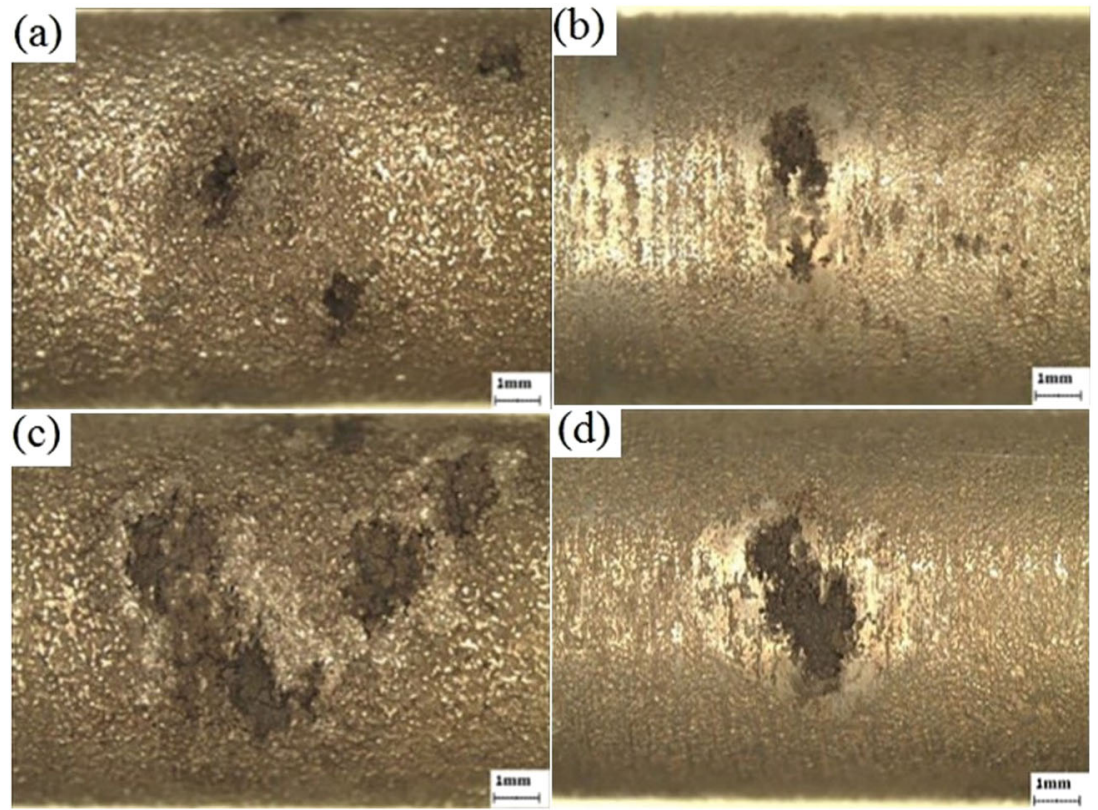

Fig. 5 Surface morphologies of the SLMed AISi10Mg alloy after immersion in $3.5 \mathrm{wt} . \% \mathrm{NaCl}$ solution: a as-received for 15 days; $\mathbf{b}$ polished for 15 days; $\mathbf{c}$ as-received for 30 days; and $\mathbf{d}$ polished for 30 days. ${ }^{15}$ (a-d adapted with permission from ref. ${ }^{115}$, copyright Elsevier 2017 )

roughness of stainless steels. A similar trend has also been reported for other metals, such as copper ${ }^{111-113}$ and magnesium alloys. ${ }^{114}$ The obtained results on the SLMed AISi10Mg alloy in Fig. 5 indicated that the corrosion resistance of the polished SLMed parts was significantly improved compared to the as-received SLMed AISi10Mg alloy. Localised corrosion attacks, such as pitting and cracking initiation, would preferentially occur at the irregular and roughness sites on the SLMed AISi10Mg alloy caused by large amounts of cavities and other surface defects. ${ }^{95,115,116}$ Meanwhile, the surface roughness could also be substantially affected the oxidation kinetics of the SLMed alloys, especially for the case of a sintered powder. ${ }^{117,118}$ The parabolic constants of the oxidation kinetics at the initial stage for the SLMed Inconel 718 alloy under $850^{\circ} \mathrm{C}$ were two times higher than those of ground samples due to the rough surface. ${ }^{40}$

Optimising the surface finish has been a tough challenge for 3D printing processes, such as for complex structural parts, where the powder is trapped within the mesh structure during the fabrication process and difficult to remove due to blind spots. $^{119,120}$ Thus, systemic work related to surface postprocessing of AM-produced materials should be carried out because there are still a numerous knowledge gaps in this aspect.

\section{Anisotropy}

The anisotropy in the SLMed parts is usually caused by the different solidification rates in different directions, and heat conductivity in the building direction ( $z$-axis) is typically faster than that in the other two spatial directions ( $x$ - and $y$ - axes) due to the high-heat transfer efficiency of the pre-deposited metals. ${ }^{121-123}$ The microstructural anisotropy in the SLMed parts usually leads to anisotropic mechanical properties ${ }^{124-126}$ and corrosion behaviours. $^{127,128}$ For the mechanical properties, there was a larger elongation along the building direction than in the other two spatial directions due to the grain growth mainly occurring along the building direction, such as for stainless steels and CoCrW alloys. ${ }^{129-131}$ Regarding the anisotropic corrosion behaviours in a Ti6Al4V alloy, the corrosion rates of the SLMed parts were relatively small and changed little with different research planes in chloride solution. However, in an aggressive solution, such as $1 \mathrm{M}$ $\mathrm{HCl}$, the XY-plane of the SLMed Ti6Al4V alloy showed a lower passive current density (approximately by half) than the XZ-plane in Fig. $6 b^{58}$ which was attributed to the decreased amount of $\alpha^{\prime}$-martensitic and the increased amount of $\beta$-phase on the XYplane, as displayed in Fig. $6 c$, d. The metastable $a^{\prime}$-martensitic phase was formed under high-thermal gradients during the SLM 
process and the acicular $a^{\prime}$-martensitic phase is in a high-energy state with regard to corrosion, which led to a decreased uniform corrosion resistance for the XZ-plane in an acidic environment. ${ }^{132}$

The distinction in the corrosion behaviour can also be attributed to the physical structures in the different planes, such as for $\mathrm{Al}-\mathrm{Si}$ alloys $^{127}$ and nickel-based alloys. ${ }^{133}$ The XZ-plane of the SLMed Al12Si alloy exhibited better pitting corrosion resistance compared with the XY-plane in chloride solution as displayed in Fig. 7a, b. The corrosion products on the XY-plane extruded the small-bore and deep $\mathrm{Si}$ shells on the substrate and the chloride ions continuously penetrated the aluminium substrate with the cracking of the Si shells, therefore, severe pitting corrosion was ultimately induced as displayed in Fig. 7c. However, the corrosion products deposited in the shallow and large-bore Si shells for the XZ-plane on the SLMed AI12Si alloy, and the undamaged Si shells and formed oxide film constituted a protective layer to protect the aluminium substrate from the further attack of chloride ions, thereby displaying excellent pitting corrosion resistance for the $\mathrm{XZ}$-plane, as shown in Fig. 7d.

\section{SPECIAL CORROSION ISSUES OF SEVERAL 3D PRINTED MATERIALS}

Ti-based alloys

As titanium combines broad industrial application in highperformance parts with high machining costs, hard moulding and a long lead time in conventional processing, titanium and titanium alloys are of utmost interest with regard to AM techniques. ${ }^{134-141}$ By one calculation, a $50 \%$ reduction of production costs was reported for a wrought titanium alloy engine bracket using the AM method. ${ }^{142}$ Among titanium alloys, Ti6Al4V is the most widely used material for many engineering parts and biomedical implants. A study conducted by Dai et al. ${ }^{132}$ showed that the SLMed Ti6Al4V exhibited a higher passive current density and a lower pitting potential ( $150 \mathrm{mV}$ lower) in chloride solution compared to the wrought counterparts due to the existence of metastable $a^{\prime}$-martensite as displayed in Fig. 8a. The martensitic transformation occurred due to the very high cooling rate and the acicular $a^{\prime}$-martensite was well distributed throughout the microstructure, accompanied by some typical long and columnar prior $\beta$-grains, as shown in Fig. 8b. ${ }^{19,143}$ Additionally, the volume fractions of the $\beta$-phase for the commercial and the SLMed Ti6Al4V alloy were about $13.3 \%$ and $5.0 \%$, respectively. ${ }^{132}$ It is known that the $\beta$-phase contains more $\mathrm{V}$ content and that the oxide film formed on the $\beta$-phase is more stable than that on the $a$-phase, which plays an important role in improving its corrosion resistance. ${ }^{144}$ Therefore, it is reasonable to conclude that the SLMed Ti6Al4V alloy exhibit poorer corrosion resistance compared to the commercial alloy. ${ }^{145}$ The acicular $a^{\prime}$-martensite can vanish gradually and transform into $a$-martensite with increasing heattreatment temperature, therefore, a plate-shaped $a$-phase and a lamellar $a+\beta$ mixture form continuously. ${ }^{146-149}$ However, the grain size also increased after the heat treatment and weakened its passivation property, which overwhelmed the decreasing amount of the $a^{\prime}$-phase on corrosion resistance, ${ }^{150}$ so the heat
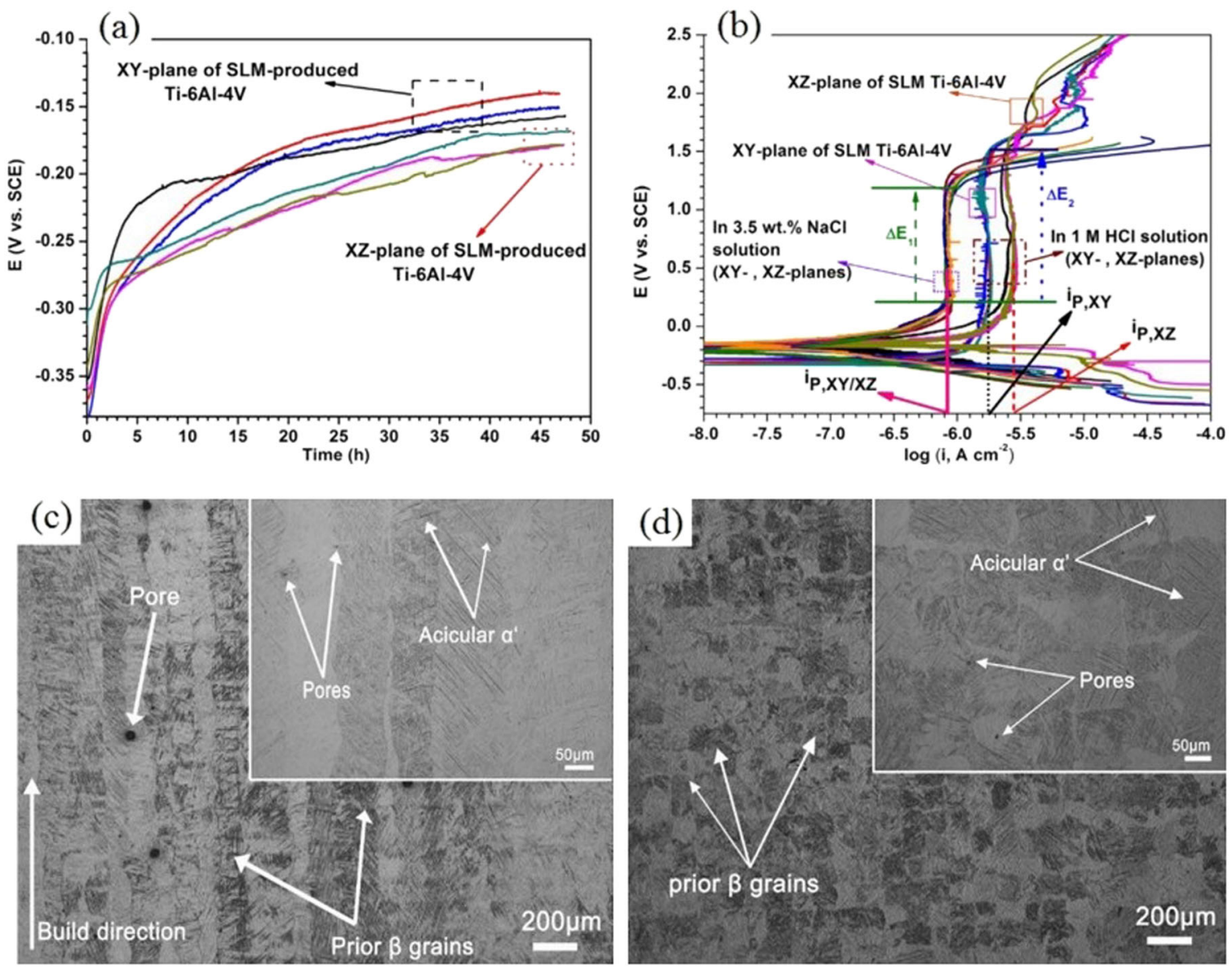

Fig. 6 a Corrosion potentials and $\mathbf{b}$ potentiodynamic polarisation curves for the XY- and XZ-planes of the SLMed Ti6Al4V alloy, microstructures of the $\mathbf{c}$ XZ-plane and $\mathbf{d}$ XY-plane of the SLMed Ti6Al4V sample. ${ }^{58}$ (a-d adapted with permission from ref. ${ }^{58}$, copyright Elsevier 2016) 
(a)
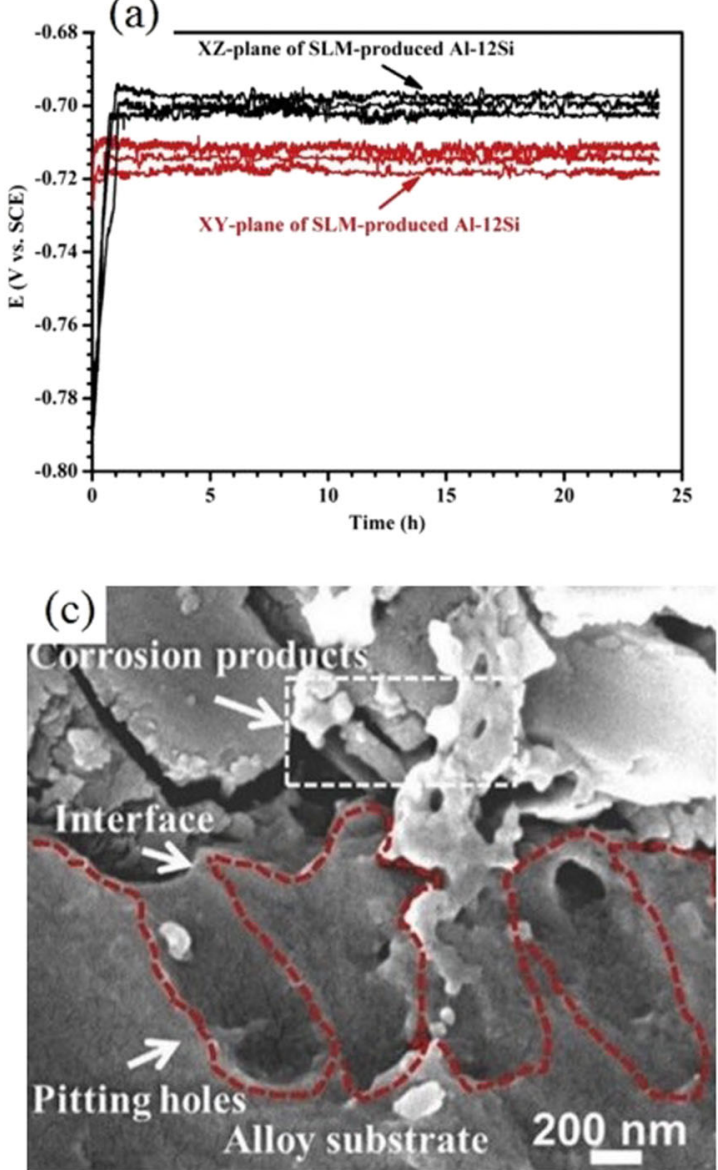

(b)

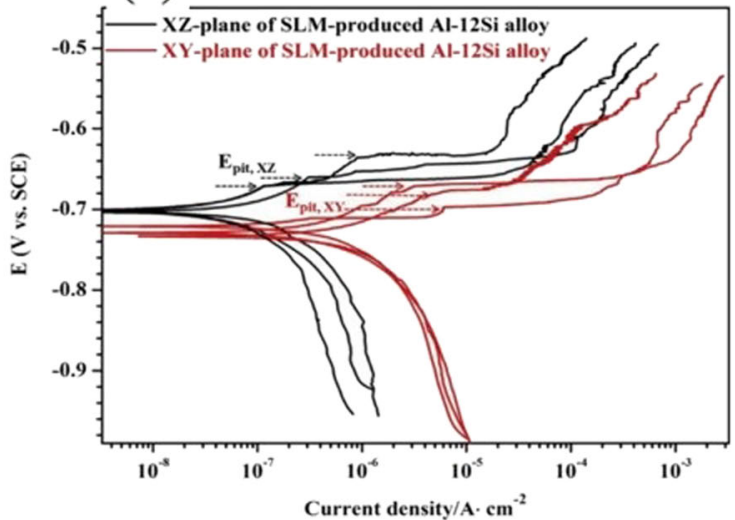

(d)

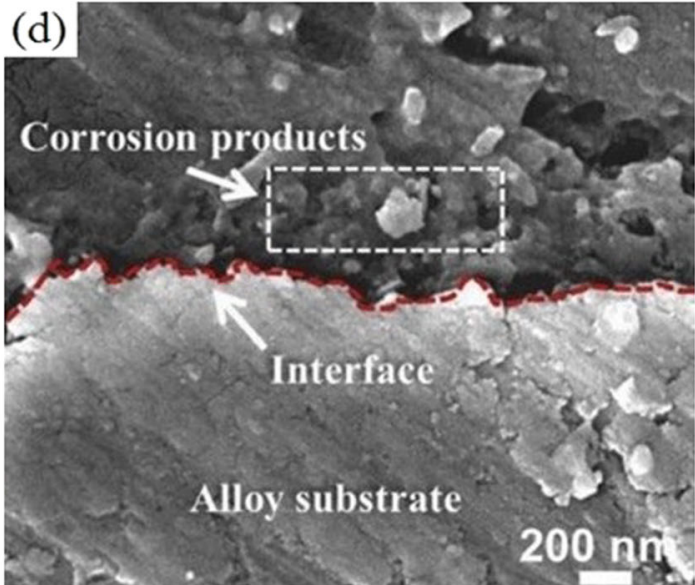

Fig. 7 a Corrosion potentials and $\mathbf{b}$ potentiodynamic polarisation curves of the XY-and XZ-planes for the SLMed Al12Si alloy in the aerated $3.5 \mathrm{wt} . \% \mathrm{NaCl}$ and SEM images of corrosion morphologies on $\mathbf{c}$ the XY- and $\mathbf{d} \mathrm{XZ}$-planes. ${ }^{127}$ (a-d adapted with permission from ref. ${ }^{127}$, copyright Elsevier 2018)
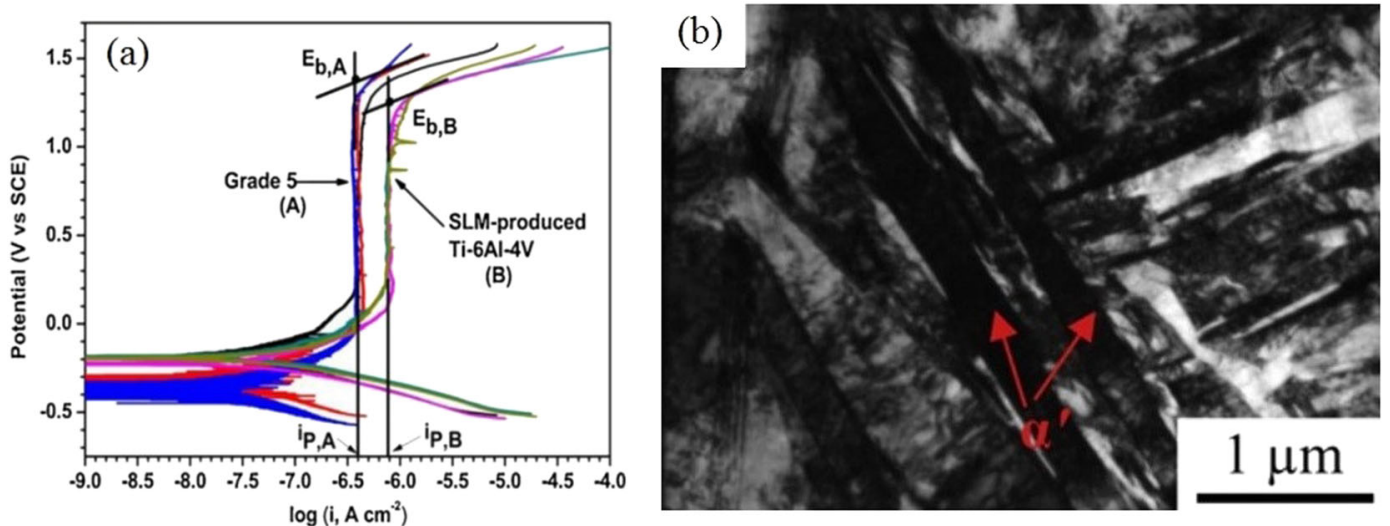

Fig. 8 a Potentiodynamic polarisation curves for the SLMed Ti6Al4V alloy and commercial Grade 5 alloy in $3.5 \mathrm{wt} . \%$ NaCl solution ${ }^{132}$ and b bright-field TEM image of the as-received SLMed Ti6Al4V alloy. ${ }^{119}$ (a adapted with permission from ref. ${ }^{132}$, copyright Elsevier 2015) (b adapted with permission from ref. ${ }^{119}$, copyright Elsevier 2015)

treatment was not favourable for improving the corrosion resistance of the SLMed Ti6AI4V alloy.

Other studies with the SLMed Ti-based alloys were also investigated, including Ti24Nb4Zr8Sn for biomedical applications, ${ }^{85,151-153}$ Ti6.5Al3.5Mo1.5Zr0.3Si for aerospace applications $^{154,155}$ and so on.
Al-based alloys

The SLM of the following aluminium alloys has been investigated: $\mathrm{Al}-\mathrm{Cu},{ }^{156-158} \mathrm{Al}-\mathrm{Zn},{ }^{159} \mathrm{AlSi} 12,{ }^{160-163} \mathrm{AlSi} 50,{ }^{164}$ and AlSi10Mg, ${ }^{70,115,165-172}$ with AlSi10Mg receiving the most attention.

The microstructure of the SLMed AISi10Mg alloy was characterised as a fine cellular-dendritic pattern, and silicon was found 
to be located primarily at the cellular boundaries, as displayed in Fig. $9 .^{173-175}$ The potential of the aluminium phase was lower than that of the silicon phase, leading to galvanic corrosion and Fig. 9d displays the intercellular network of silicon in the corroded areas for the SLMed AISi10Mg alloy in chloride solution. Thus, post heat treatments were conducted on the SLMed AISi10Mg alloy to homogenise its composition and improve the corrosion resistance. ${ }^{176,177}$ However, the silicon in the SLMed 2024 aluminium alloy promoted $\mathrm{Al}_{2} \mathrm{Cu}$ precipitation and hindered the $\mathrm{Al}_{2} \mathrm{CuMg}$ phase, which led to a decreased uniform corrosion rate $(5$ times lower) compared to that for the commercial 2024 aluminium alloy in chloride solution. Moreover, a thicker aluminium oxide film was obtained on the SLMed 2024 aluminium alloy in comparison to that on the wrought counterpart. ${ }^{178}$

\section{Fe-based alloys}

Austenitic stainless steels (such as $304 \mathrm{~L}$ and $316 \mathrm{~L}$ ) can still exhibit a complete austenitic phase after SLM fabrication, ${ }^{37,179,180}$ but the ferrite phase can be formed during laser melting deposition (with a slower cooling rate compared with SLM). ${ }^{8,181-183}$ In the SLMed $316 \mathrm{~L}$ stainless steel, there were many dislocation cells inside the grain, which led to a higher hardness and strength in comparison to the wrought counterpart. ${ }^{36,184-187}$ Moreover, nanoscale inclusions (diameter ranging from 100 to $200 \mathrm{~nm}$ ) were extensive in the SLMed $316 \mathrm{~L}$ substrate and were enriched with $\mathrm{Si}, \mathrm{Al}, \mathrm{Mn}$ and $\mathrm{O}$ as displayed in Fig. 10b, c, which was also confirmed by other reports. $^{50,188-190}$ The oxide inclusions of this scale were not deleterious to the pitting corrosion resistance. ${ }^{191,192}$ However, no MnS inclusions or large (Al, Ca)-oxide precipitates have yet been observed in the SLMed 316L stainless steel, which should be attributed to the extremely high solidification rate during the SLM process, however, there was enough time for the element diffusion (such as $\mathrm{Mn}$ and $\mathrm{S}$ ) to form those inclusions during the traditional casting process. ${ }^{193,194}$ Thus, a higher pitting potential
( $300 \mathrm{mV})$ was obtained for the SLMed $316 \mathrm{~L}$ stainless steel compared to that of the wrought material in $3.5 \mathrm{wt} . \%$ chloride solution, as displayed in Fig. 10d, and the porosity of the SLMed $316 \mathrm{~L}$ stainless steel in his work had no effect on the pitting potential (the porosities were all below $0.5 \%)^{69}$

Meanwhile, Sander et al. ${ }^{69}$ emphasised that there was a lower frequency of metastable pitting for the SLMed $316 \mathrm{~L}$ specimens than that for the wrought in chloride solution. They also pointed out that the protective potential decreased with increasing porosity, which could be ascribed to the poor re-passivation ability at the pore sites. An Auger electron spectroscopy measurement confirmed that the passive film formed on the SLMed 316L stainless steel in simulated body fluid for $96 \mathrm{~h}$ was $\sim 1.5$ times thicker than the film formed on the wrought $316 \mathrm{~L}$ stainless steel, as displayed in Fig. 10e, f. Similar results were also confirmed on the SLMed AA2024 aluminium alloys. ${ }^{177}$ At the same time, oxidation reactions preferentially occurred at the high dislocations sites of the 304 stainless steel due to the high activation energy of localised lattice distortion, ${ }^{195}$ which means that thicker passive film can be formed on the SLMed samples due to the high density of sub-grain boundaries. Stress corrosion cracking is usually detrimental for stainless steels, and the influence of the crack orientation was critical in evaluating the stress corrosion cracking property because the SLMed $316 \mathrm{~L}$ stainless steel exhibited an anisotropic microstructure and complex geometry. ${ }^{121}$ The SLMed 316L parts showed a higher crack growth rate along the building direction than the other two directions or the wrought material and the differences were more than a factor of two $\left(1.2 \times 10^{-7} \mathrm{~mm} / \mathrm{s}\right.$ vs. $5 \times 10^{-8} \mathrm{~mm} / \mathrm{s}$ in $2 \mathrm{ppm}$ dissolved oxygen) as displayed in Fig. 11. The crack growth rate of the SLMed 316L stainless steel perpendicular to the building orientation was similar to the wrought $316 \mathrm{~L}$ stainless steel. ${ }^{196}$ The slower crack growth perpendicular to the building orientation may be due to the difficulties the crack encountered when attempting to cut through the vertically oriented and closely spaced columnar
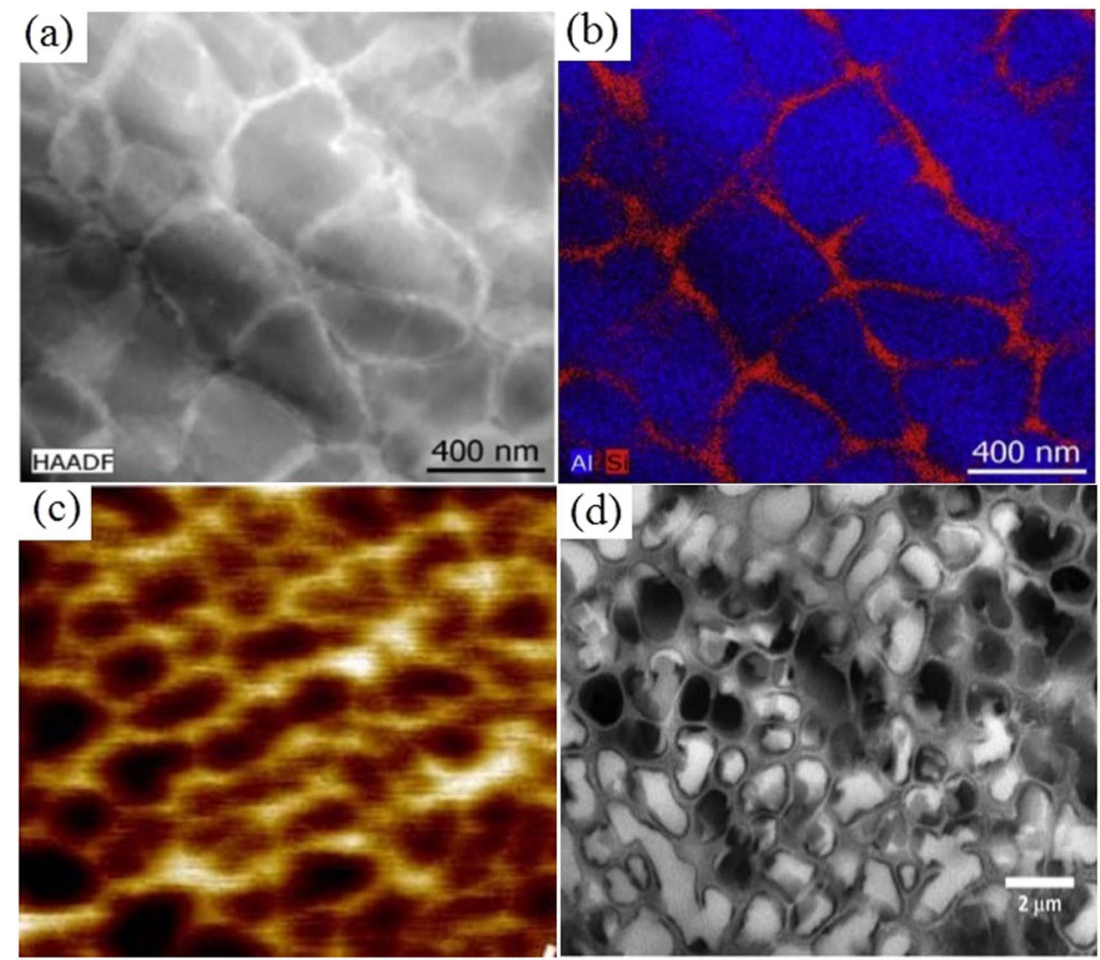

Fig. 9 a STEM HAADF image of SLMed AISi10Mg, b Al and Si X-ray map ${ }^{173}$ and $\mathbf{c}$ the surface potential mapping results (Colour bar: $210 \mathrm{mV}$ range) and $\mathbf{d}$ the corroded morphology in $\mathrm{NaCl}$ solution. ${ }^{207}$ (a and $\mathbf{b}$ adapted with permission from ref. ${ }^{1 / 3}$, copyright Elsevier 2016 ) (c and d adapted with permission from J. Electrochem. Soc., 164, C27, 2017, copyright 2017. The Electrochemical Society) 

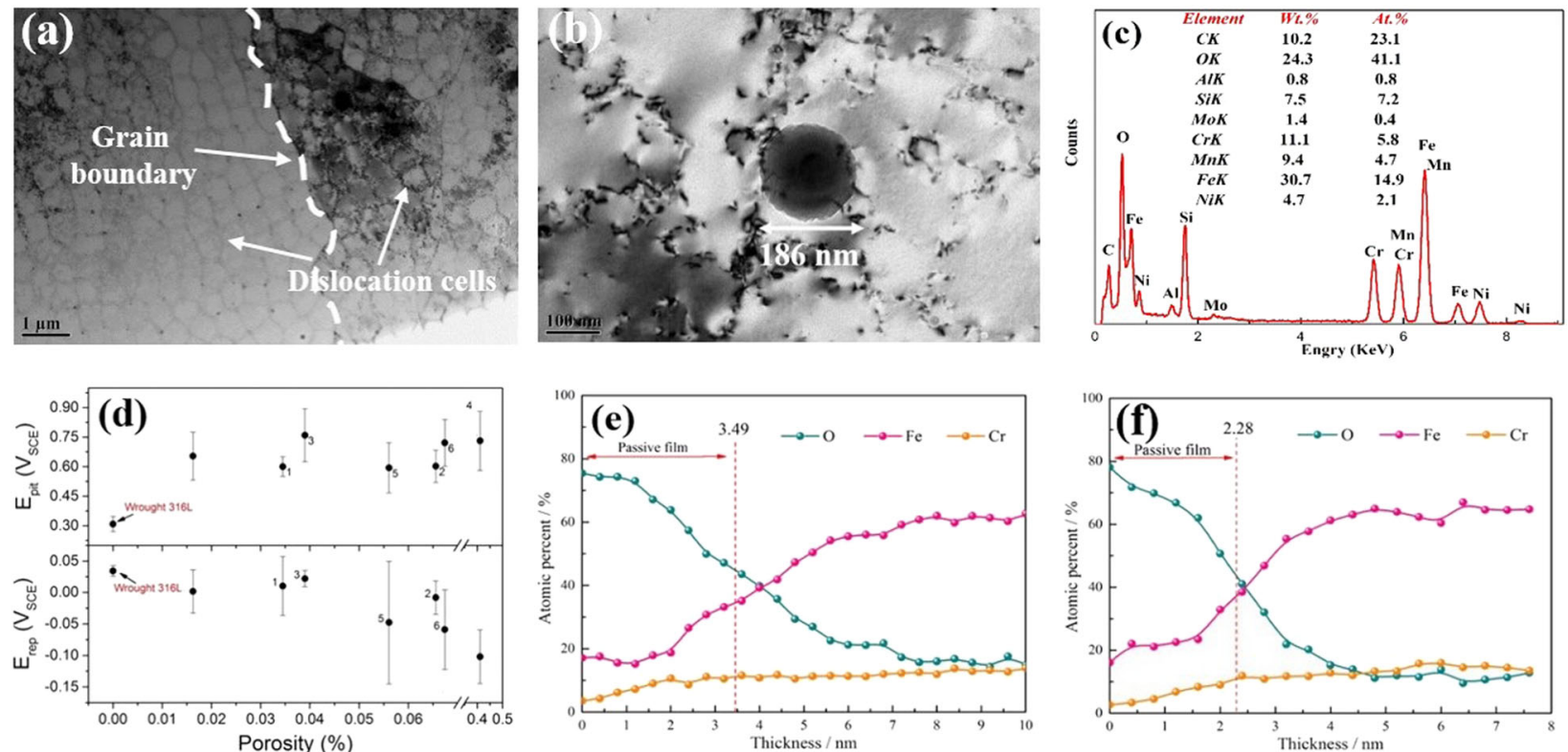

Fig. 10 Transmission electron microscopy images $\mathbf{a}, \mathbf{b}$ and $\mathbf{c}$ the EDS results of the nano-inclusion of the SLMed $316 \mathrm{~L}$ specimens, ${ }^{36,82} \mathbf{d} E_{\text {pit }}$ and $E_{\text {rep }}$ values against the respective sample porosity in $3.5 \mathrm{wt} . \%$ chloride solution, ${ }^{69}$ and passive film thickness on the e SLMed and $\mathbf{f}$ wrought $316 \mathrm{~L}$ stainless steel after immersion in simulated body fluid for $96 \mathrm{~h}$ obtained by auger electron spectroscopy. ${ }^{37}$ (a adapted with permission from ref. ${ }^{36}$, copyright Elsevier 2018) (b and $\mathbf{c}$ adapted with permission from ref. ${ }^{82}$, copyright Elsevier 2018) (d adapted with permission from $J$. Electrochem. Soc., 164, C250, 2017, copyright 2017. The Electrochemical Society) (e and f adapted with permission from ref. ${ }^{37}$, copyright Elsevier 2018)
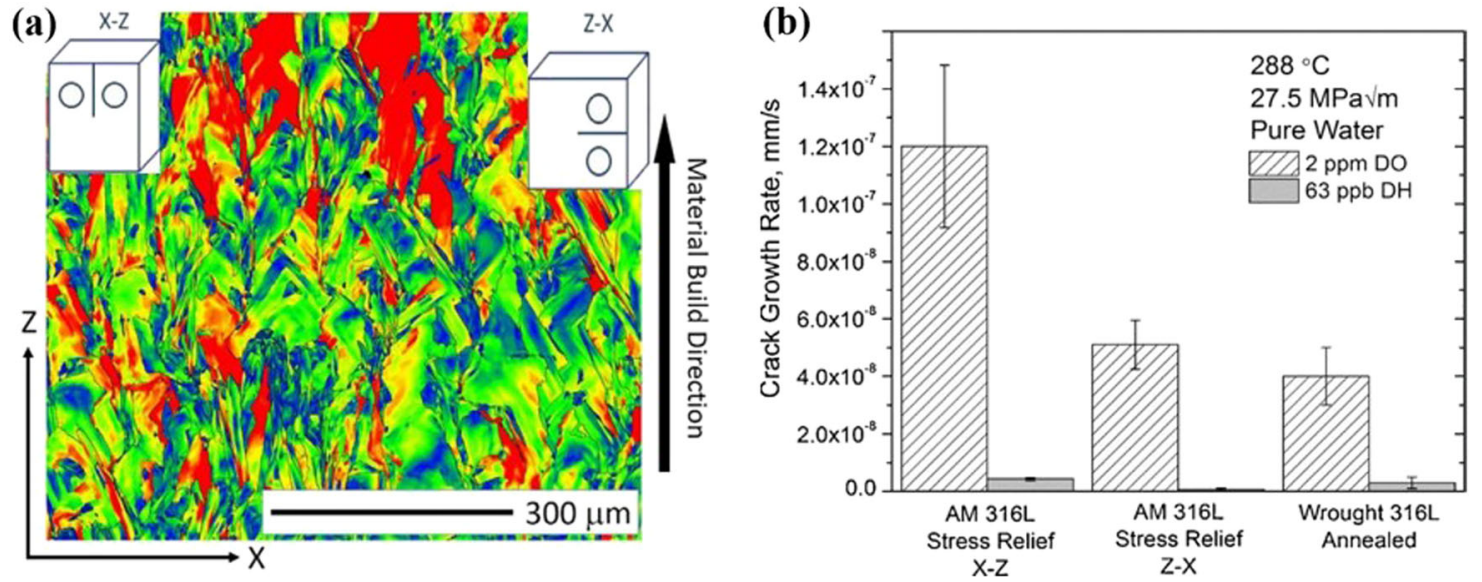

Fig. 11 a EBSD map and $\mathbf{b}$ stress corrosion cracking growth rate of the SLMed (stress-relieved with no additional cold work) and wrought $316 \mathrm{~L}$ stainless steel in normal ( 2 ppm dissolved oxygen) and hydrogen water chemistry environment ( 63 ppb dissolved hydrogen). ${ }^{196}$ " $X^{\prime \prime}$ refers to the direction perpendicular to the material building direction, and " $Z$ " refers to the direction parallel to the material building direction. (a and b adapted with permission from ref. ${ }^{196}$, copyright Elsevier 2018)

grains. The crack paths were more tortuous and encountered more grain boundaries than those propagating on the plane perpendicular to the building orientation. ${ }^{196,197}$ The microstructural anisotropy can be eliminated after high-temperature recrystallisation annealing and the results revealed that the annealed SLMed 316L stainless steel showed a slower crack growth rate than the stress-relieved counterpart. ${ }^{128}$ Thus, recrystallisation annealing heat treatment is necessary for the SLMed $316 \mathrm{~L}$ stainless steel to improve its resistance against stress corrosion cracking.

\section{CONCLUSIONS AND FUTURE WORK}

An overview of the current state of some metallic materials fabricated by SLM technology was presented with a focus on the relationship between the internal microstructures and the related corrosion properties. A consensus was reached that a hightemperature gradient involved in the SLM process typically yields significant grain refinement and a high density of dislocations, leading to a notably high tensile strength. For corrosion resistance, it depends on whether or not phases or structures with poorer corrosion resistance are generated compared to the traditional processed counterparts. In the near future, the variety of AM materials is expected to increase, and the optimisation of the fabrication parameters to obtain a high strength, low surface roughness and minimal porosity will always be the focus. However, the internal relationship between the microstructural features and the corrosion behaviour of the printed parts should also be studied systematically. Research should begin with the 


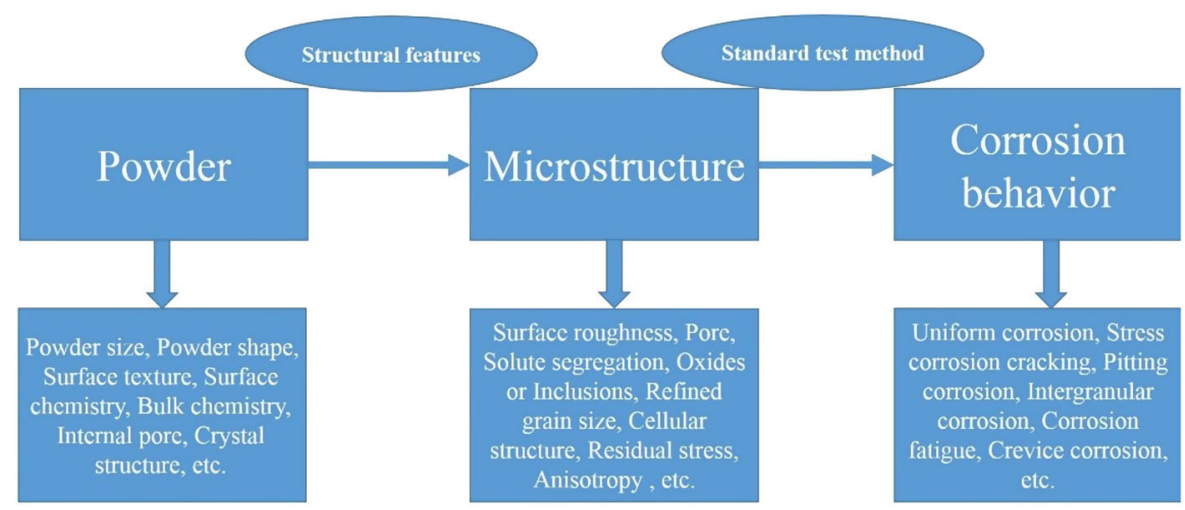

Fig. 12 Schematic diagram involving the powder, microstructure and the related corrosion behaviour for AM-produced components

input powder material properties and their effects on the building process. When characterising a powder, it is important that the following three main parts are included: particle morphology, particle chemistry and particle microstructure. ${ }^{198-201}$ Currently, research is primarily focused on the morphological characterisation of powders and their effect on the properties of fabricated parts. The properties of the final consolidated components, such as the mechanical and anti-corrosive properties, may also be influenced by whether the feedstock powders are argon- or nitrogen-atomised and whether the build chambers are argon- or nitrogen-purged. ${ }^{202-205}$

Figure 12 shows a schematic diagram involving the powder, microstructure and related corrosion behaviour of AM-produced components. It is necessary to establish the relationship between the key structural features and corrosion resistance. For example, typical MnS inclusions formed in wrought 316L stainless steel were substituted by nano sized $\mathrm{Mn}$-Si oxides in the SLMed counterparts, reducing the pitting susceptibility, ${ }^{36,188}$ and microstructural anisotropy for the SLMed parts led to different SCC growth rates. ${ }^{196}$ For the corrosion testing methods, there is an obvious lack of standards for which baseline or standardised tests are executed, and up to now, a broad range of different corrosion test methods (such as corrosion potential, polarisation, impedance spectroscopy, weight-loss experiment, etc.), make cross comparisons difficult. The acceptance of standardised testing procedures formulated by professional bodies, such as the ASTM in the United States, is one approach to solve this problem.

In general, the defects in the SLMed parts (such as pores and MPBs) usually comprise the corrosion resistance, therefore, a heat treatment combining the hot isostatic pressing should be considered to homogenise the composition and microstructure, and reduce the porosity. Another post-processing method involves surface treatment, but surface treatment has been an ongoing challenge with the SLMed metals from the initiation of this technology. Surface modification techniques, including sand blasting, electrochemical deposition, alkali-acid-heat treatment, electrochemical etching and micro-arc oxidation, can be chosen according to the characteristics of the material. However, surface modification of printed porous metals is more challenging than that of solid implants because of the compatibility with widely used line-of-sight techniques; thus, the choice of available methods is very limited. Therefore, further research in this area is also warranted.

\section{ACKNOWLEDGEMENTS}

This work was supported by the National Key Research and Development Programme of China (No. 2017YFB 0702300), Fundamental Research Funds for the Central Universities (No. FRF-TP-17-002B), National Natural Science Foundation of China (No.51671029).

\section{AUTHOR CONTRIBUTIONS}

D.K., X.N. and C.D. reviewed and analysed the literature on the corrosion of selective laser melted alloys. D.K. and C.D. wrote the paper. C.D. and X.L. reviewed and modified the paper and final approval of the version to be published was given by all authors.

\section{ADDITIONAL INFORMATION}

Competing interests: The authors declare no competing interests.

Publisher's note: Springer Nature remains neutral with regard to jurisdictional claims in published maps and institutional affiliations.

\section{REFERENCES}

1. Bourell, D. L. Perspectives on additive manufacturing. Ann. Rev. Mater. Res 46, 1-18 (2016).

2. Rosen, D. W. A review of synthesis methods for additive manufacturing. Virtu. Phys. Prototyp. 11, 305-317 (2016).

3. Mallik, M. K., Rao, C. S. \& Kesava rao, V. V. S. Effect of heat treatment on hardness of Co-Cr-Mo alloy deposited with laser engineered net shaping. Proced. Eng. 97, 1718-1723 (2014).

4. Hu, Y. B. \& Cong, W. L. A review on laser deposition-additive manufacturing of ceramics and ceramic reinforced metal matrix composites. Ceram. Int. 44, 20599-20612 (2018).

5. Fatoba, O. S., Akinlabi, S. A. \& Akinlabi, E. T. Laser metal deposition influence on the mechanical properties of steels and stainless steel composites: a review. Mater. Today-Proc. 5, 18603-18620 (2018).

6. Shi, Y. N., Lu, Z., Ren, Y. H. \& Yang, G. Microstructure and tensile properties of laser engineered net shaped reduced activation ferritic/martensitic steel. Mater. Charact. 144, 554-562 (2018).

7. Li, Y. Z., Hu, Y. B., Cong, W. L., Zhi, L. \& Guo, Z. N. Additive manufacturing of alumina using laser engineered net shaping: Effects of deposition variables. Ceram. Int. 43, 7768-7775 (2017).

8. Zietala, M. The microstructure, mechanical properties and corrosion resistance of $316 \mathrm{~L}$ stainless steel fabricated using laser engineered net shaping. Mat. Sci. Eng. a-Struct. 677, 1-10 (2016).

9. Murr, L. E. Fabrication of metal and alloy components by additive manufacturing: examples of 3D materials science. J. Mater. Res Tech. 1, 42-54 (2012).

10. Murr, L. E. Metal fabrication by additive manufacturing using laser and electron beam melting technologies. J. Mater. Sci. Tech. 28, 1-14 (2012).

11. Korner, C. Additive manufacturing of metallic components by selective electron beam melting - a review. Int Mater. Rev. 61, 361-377 (2016).

12. Galati, M. \& luliano, L. A literature review of powder-based electron beam melting focusing on numerical simulations. Addit. Manuf. 19, 1-20 (2018).

13. Singh, S., Sharma, V. S. \& Sachdeva, A. Progress in selective laser sintering using metallic powders: a review. Mater. Sci. Tech.-Lond. 32, 760-772 (2016).

14. Sing, S. L. et al. Direct selective laser sintering and melting of ceramics: a review. Rapid Prototyp. J. 23, 611-623 (2017).

15. Dinda, G. P., Dasgupta, A. K. \& Mazumder, J. Texture control during laser deposition of nickel-based superalloy. Scr. Mater. 67, 503-506 (2012).

16. Jia, Q. \& Gu, D. Selective laser melting additive manufacturing of Inconel 718 superalloy parts: Densification, microstructure and properties. J. Alloy Compd. 585, 713-721 (2014). 
17. Suzuki, M., Yamaguchi, R., Murakami, K. \& Nakada, M. Inclusion particle growth during solidification of stainless steel. ISIJ Int. 41, 247-256 (2001).

18. Kong, D. et al. High-throughput fabrication of nickel-based alloys with different $\mathrm{Nb}$ contents via a dual-feed additive manufacturing system: Effect of $\mathrm{Nb}$ content on microstructural and mechanical properties. J. Alloy Compd. 785, 826-837 (2019).

19. Van Bael, S. et al. The effect of pore geometry on the in vitro biological behavior of human periosteum-derived cells seeded on selective laser-melted Ti6Al4V bone scaffolds. Acta Biomater. 8, 2824-2834 (2012).

20. Olakanmi, E. O., Cochrane, R. F. \& Dalgarno, K. W. A review on selective laser sintering/melting (SLS/SLM) of aluminium alloy powders: Processing, microstructure, and properties. Prog. Mater. Sci. 74, 401-477 (2015).

21. Karia, M. C., Popat, M. A. \& Sangani, K. B. Selective laser melting of inconel super alloy-a review. AIP Conf. Proc. 1859, 1-7 (2017).

22. Zhang, J. L., Song, B., Wei, Q. S., Bourell, D. \& Shi, Y. S. A review of selective laser melting of aluminum alloys: processing, microstructure, property and developing trends. J. Mater. Sci. Tech. 35, 270-284 (2019).

23. Morgan, R. H., Papworth, A. J., Sutcliffe, C., Fox, P. \& O'Neill, W. High density net shape components by direct laser re-melting of single-phase powders. J. Mater. Sci. 37, 3093-3100 (2002).

24. Carboni, C., Peyre, P., Beranger, G. \& Lemaitre, C. Influence of high power diode laser surface melting on the pitting corrosion resistance of type $316 \mathrm{~L}$ stainless steel. J. Mater. Sci. 37, 3715-3723 (2002).

25. Zhang, K. M., Zou, J. X., Grosdidier, T., Dong, C. \& Yang, D. Z. Improved pitting corrosion resistance of AISI $316 \mathrm{~L}$ stainless steel treated by high current pulsed electron beam. Surf. Coat. Tech. 201, 1393-1400 (2006).

26. Santo, L. Laser cladding of metals: a review. Int J. Surf. Sci. Eng. 2, 327-336 (2008).

27. Weng, F., Chen, C. Z. \& Yu, H. J. Research status of laser cladding on titanium and its alloys: A review. Mater. Des. 58, 412-425 (2014).

28. Liu, J. L., Yu, H. J., Chen, C. Z., Weng, F. \& Dai, J. J. Research and development status of laser cladding on magnesium alloys: A review. Opt. Laser Eng. 93 195-210 (2017).

29. Li, R. D. et al. Selective laser melting of a novel Sc and Zr modified Al-6.2 Mg alloy: Processing, microstructure, and properties. Powder Tech. 319, 117-128 (2017).

30. Das, S., Bourell, D. L. \& Babu, S. S. Metallic materials for 3D printing. MRS Bull. 41, 729-741 (2016).

31. Zlobina, I. V., Bekrenev, N. V. \& Pavlov, S. P. A proposal to improve a 3D printing technology of composite materials products. IOP Conf. Ser.: Mater. Sci. Eng. 286, 012017 (2017).

32. Zhu, Y., Chen, X., Zou, J. \& Yang, H. Sliding wear of selective laser melting processed Ti6Al4V under boundary lubrication conditions. Wear 368-369, 485-495 (2016).

33. Zhu, Y., Zou, J. \& Yang, H. -y Wear performance of metal parts fabricated by selective laser melting: a literature review. J. Zhejiang Univ.-Sci. A 19, 95-110 (2018).

34. Shipley, $H$. et al. Optimisation of process parameters to address fundamental challenges during selective laser melting of Ti-6Al-4V: A review. Int J. Mach. Tool. Man. 128, 1-20 (2018).

35. DebRoy, T. et al. Additive manufacturing of metallic components-Process, structure and properties. Prog. Mater. Sci. 92, 112-224 (2018).

36. Kong, D. et al. Bio-functional and anti-corrosive 3D printing $316 \mathrm{~L}$ stainless steel fabricated by selective laser melting. Mater. Des. 152, 88-101 (2018).

37. Man, C. et al. The enhancement of microstructure on the passive and pitting behaviors of selective laser melting $316 \mathrm{~L}$ SS in simulated body fluid. App/ Surf. Sci. 467-468, 193-205 (2019).

38. Li, R., Liu, J., Shi, Y., Wang, L. \& Jiang, W. Balling behavior of stainless steel and nickel powder during selective laser melting process. Int. J. Adv. Manufact. Tech. 59, 1025-1035 (2011).

39. Martin, J. H. et al. 3D printing of high-strength aluminium alloys. Nature 549, 365 (2017).

40. Sanviemvongsak, T., Monceau, D. \& Macquaire, B. High temperature oxidation of IN 718 manufactured by laser beam melting and electron beam melting: Effect of surface topography. Corros. Sci. 141, 127-145 (2018).

41. Lu, L. -X., Sridhar, N. \& Zhang, Y. -W. Phase field simulation of powder bed-based additive manufacturing. Acta Mater. 144, 801-809 (2018).

42. Lewandowski, J. J. \& Seifi, M. Metal Additive manufacturing: a review of mechanical properties. Annu. Rev. Mater. Res 46, 151-186 (2016).

43. Frazier, W. E. Metal additive manufacturing: a review. J. Mater. Eng. Perform. 23, 1917-1928 (2014).

44. Townsend, A., Senin, N., Blunt, L., Leach, R. K. \& Taylor, J. S. Surface texture metrology for metal additive manufacturing: a review. Precis Eng. 46, 34-47 (2016).
45. Domashenkov, A. et al. Microstructure and physical properties of a Ni/Fe-based superalloy processed by Selective Laser Melting. Addit. Manuf. 15, 66-77 (2017).

46. Gorsse, S., Hutchinson, C., Goune, M. \& Banerjee, R. Additive manufacturing of metals: a brief review of the characteristic microstructures and properties of steels, Ti-6Al-4V and high-entropy alloys. Sci. Technol. Adv. Mater. 18, 584-610 (2017).

47. Strossner, J., Terock, M. \& Glatzel, U. Mechanical and microstructural investigation of nickel-based superalloy IN718 manufactured by selective laser melting (SLM). Adv. Eng. Mater. 17, 1099-1105 (2015).

48. Yap, C. Y., Tan, H. K., Du, Z. L., Chua, C. K. \& Dong, Z. L. Selective laser melting of nickel powder. Rapid Prototyp. J. 23, 750-757 (2017).

49. Qiu, C. L., Chen, H. X., Liu, Q., Yue, S. \& Wang, H. M. On the solidification behaviour and cracking origin of a nickel-based superalloy during selective laser melting. Mater. Charact. 148, 330-344 (2019).

50. Saeidi, K., Gao, X., Zhong, Y. \& Shen, Z. J. Hardened austenite steel with columnar sub-grain structure formed by laser melting. Mat. Sci. Eng. a-Struct. 625, 221-229 (2015).

51. Li, R. D. et al. Selective laser melting of an equiatomic CoCrFeMnNi high-entropy alloy: Processability, non-equilibrium microstructure and mechanical property. J. Alloy Compd. 746, 125-134 (2018).

52. Luo, S. C. et al. Selective laser melting of an equiatomic AlCrCuFeNi high-entropy alloy: Processability, non-equilibrium microstructure and mechanical behavior. $J$. Alloy Compd. 771, 387-397 (2019).

53. Wen, S. F. et al. Effect of molten pool boundaries on the mechanical properties of selective laser melting parts. J. Mater. Process Tech. 214, 2660-2667 (2014).

54. Ganesh, P. et al. Studies on pitting corrosion and sensitization in laser rapid manufactured specimens of type 316L stainless steel. Mater. Des. 39, 509-521 (2012).

55. Miranda, G. et al. Predictive models for physical and mechanical properties of $316 \mathrm{~L}$ stainless steel produced by selective laser melting. Mat. Sci. Eng. a-Struct. 657, 43-56 (2016).

56. Xie, F. X., He, X. B., Cao, S. L. \& Qu, X. H. Structural and mechanical characteristics of porous $316 \mathrm{~L}$ stainless steel fabricated by indirect selective laser sintering. $J$. Mater. Process Tech. 213, 838-843 (2013).

57. $\mathrm{Ni}, \mathrm{X}$. et al. Corrosion behavior of $316 \mathrm{~L}$ stainless steel fabricated by selective laser melting under different scanning speeds. J. Mater. Eng. Perform. 27, 3667-3677 (2018).

58. Dai, N. A. W. et al. Distinction in corrosion resistance of selective laser melted Ti6Al-4V alloy on different planes. Corros. Sci. 111, 703-710 (2016).

59. Yang, G. Q. et al. Additive manufactured bipolar plate for high-efficiency hydrogen production in proton exchange membrane electrolyzer cells. Int J. Hydrog. Energ. 42, 14734-14740 (2017).

60. Sander, G. et al. Corrosion of additively manufactured alloys: a review. Corrosion 74, 1318-1350 (2018).

61. Kong, D. et al. Mechanical properties and corrosion behavior of selective lase melted $316 \mathrm{~L}$ stainless steel after different heat treatment processes. J. Mater. Sci. Tech. 35, 1499-1507 (2019).

62. Ornek, C. Additive manufacturing - a general corrosion perspective. Corros. Eng. Sci. Techn 53, 531-535 (2018).

63. Hou, B. et al. The cost of corrosion in China. NPJ Mater. Degrad. 1, 1-10 (2017)

64. Li, X. et al. Materials science: Share corrosion data. Nature 527, 441-442 (2015)

65. Otero, E. et al. Influence of microstructure on the corrosion resistance of AISI type 304L and type $316 \mathrm{~L}$ sintered stainless steels exposed to ferric chloride solution. Mater. Charact. 35, 145-151 (1995).

66. Otero, E. et al. Corrosion behaviour of aisi $304 \mathrm{I}$ and $316 \mathrm{l}$ stainless steels prepared by powder metallurgy in the presence of sulphuric and phosphoric acid. Corros. Sci. 40, 1421-1434 (1998).

67. Maximenko, A. L. \& Olevsky, E. A. Pore filling during selective laser melting assisted additive manufacturing of composites. Scr. Mater. 149, 75-78 (2018).

68. Laquai, R. et al. X-ray refraction distinguishes unprocessed powder from empty pores in selective laser melting Ti-6Al-4V. Mater. Res. Lett. 6, 130-135 (2018).

69. Sander, G. et al. On the corrosion and metastable pitting characteristics of $316 \mathrm{~L}$ stainless steel produced by selective laser melting. J. Electrochem. Soc. 164, C250-C257 (2017).

70. Kempen, K., Thijs, L., Van Humbeeck, J. \& Kruth, J. P. Processing AlSi10Mg by selective laser melting: parameter optimisation and material characterisation. Mater. Sci. Tech.-Lond. 31, 917-923 (2015).

71. Carter, L. N., Essa, K. \& Attallah, M. M. Optimisation of selective laser melting for a high temperature Ni-superalloy. Rapid Prototyp. J. 21, 423-432 (2015).

72. Yusuf, S. M. \& Gao, N. Influence of energy density on metallurgy and properties in metal additive manufacturing. Mater. Sci. Tech.-Lond. 33, 1269-1289 (2017).

73. Kluczynski, J., Sniezek, L., Grzelak, K. \& Mierzynski, J. The influence of exposure energy density on porosity and microhardness of the SLM additive manufactured elements. Materials 11, 1-10 (2018). 
74. Han, J. et al. Microstructure and mechanical property of selective laser melted Ti6Al4V dependence on laser energy density. Rapid Prototyp. J. 23, 217-226 (2017).

75. Cherry, J. A. et al. Investigation into the effect of process parameters on microstructural and physical properties of $316 \mathrm{~L}$ stainless steel parts by selective laser melting. Int J. Adv. Manuf. Tech. 76, 869-879 (2015).

76. Wei, K., Gao, M., Wang, Z. \& Zeng, X. Effect of energy input on formability, microstructure and mechanical properties of selective laser melted AZ91D magnesium alloy. Mater. Sci. Eng. A 611, 212-222 (2014).

77. Zhu, Z. G. et al. Hierarchical microstructure and strengthening mechanisms of a CoCrFeNiMn high entropy alloy additively manufactured by selective laser melting. Scr. Mater. 154, 20-24 (2018).

78. Wang, X. J., Zhang, L. C., Fang, M. H. \& Sercombe, T. B. The effect of atmosphere on the structure and properties of a selective laser melted Al-12Si alloy. Mater. Sci. Eng. A 597, 370-375 (2014).

79. Prashanth, K. G., Scudino, S., Maity, T., Das, J. \& Eckert, J. Is the energy density a reliable parameter for materials synthesis by selective laser melting? Mater. Res. Lett. 5, 386-390 (2017).

80. Geenen, K., Röttger, A. \& Theisen, W. Corrosion behavior of $316 \mathrm{~L}$ austenitic steel processed by selective laser melting, hot-isostatic pressing, and casting. Mater. Corros. 68, 764-775 (2017)

81. Schaller, R. F., Taylor, J. M., Rodelas, J. \& Schindelholz, E. J. Corrosion properties of powder bed fusion additively manufactured 17-4 PH stainless steel. Corrosion 73, 796-807 (2017).

82. Kong, D. et al. Heat treatment effect on the microstructure and corrosion behavior of $316 \mathrm{~L}$ stainless steel fabricated by selective laser melting for proton exchange membrane fuel cells. Electro. Acta 276, 293-303 (2018).

83. Mohd Yusuf, S., Nie, M., Chen, Y., Yang, S. \& Gao, N. Microstructure and corrosion performance of $316 \mathrm{~L}$ stainless steel fabricated by Selective Laser Melting and processed through high-pressure torsion. J. Alloy Compd. 763, 360-375 (2018).

84. Li, Y. J., Li, X. P., Zhang, L. C. \& Sercombe, T. B. Processing and properties of topologically optimised biomedical Ti-24Nb-4Zr-8Sn scaffolds manufactured by selective laser melting. Mat. Sci. Eng. a-Struct. 642, 268-278 (2015).

85. Liu, Y. J. et al. Microstructure, defects and mechanical behavior of beta-type titanium porous structures manufactured by electron beam melting and selective laser melting. Acta Mater. 113, 56-67 (2016).

86. Cabrini, M. et al. Statistical approach for electrochemical evaluation of the effect of heat treatments on the corrosion resistance of AlSi10Mg alloy by laser powder bed fusion. Electro. Acta 305, 459-466 (2019).

87. Xing, X. D., Duan, X. M., Jiang, T. T., Wang, J. D. \& Jiang, F. C. Ultrasonic peening treatment used to improve stress corrosion resistance of AlSi10Mg components fabricated using selective laser melting. Metals-Basel 9, 1-8 (2019).

88. Lancea, C. et al. Accelerated corrosion analysis of AISi10Mg alloy manufactured by selective laser melting (SLM). Rev. Chim.-Buchar. 69, 975-981 (2018).

89. Liang, Z. X. et al. A new high-strength and corrosion-resistant Al-Si based casting alloy. Mater. Lett. 97, 104-107 (2013).

90. Fratila-Apachitei, L. E., Apachitei, I. \& Duszczyk, J. Characterization of cast AISi (Cu) alloys by scanning Kelvin probe force microscopy. Electro. Acta 51, 5892-5896 (2006).

91. Osorio, W. R., Goulart, P. R. \& Garcia, A. Effect of silicon content on microstructure and electrochemical behavior of hypoeutectic Al-Si alloys. Mater. Lett. 62, 365-369 (2008).

92. Ni, X. et al. Anisotropy in mechanical property and corrosion resistance of $316 \mathrm{~L}$ stainless steel fabricated by selective laser melting. Int. J. Min. Met. Mater, 26, 319-328 (2018)

93. Chen, W. Effect of the particle size of $316 \mathrm{~L}$ stainless steel on the corrosion characteristics of the steel fabricated by selective laser melting. Int. J. Electrochem. Sc., 13, 10217-10232, (2018).

94. Wang, D., Liu, Y., Yang, Y. \& Xiao, D. Theoretical and experimental study on surface roughness of $316 \mathrm{~L}$ stainless steel metal parts obtained through selective laser melting. Rapid Prototyp. J. 22, 706-716 (2016).

95. Boschetto, A., Bottini, L. \& Veniali, F. Roughness modeling of AlSi10Mg parts fabricated by selective laser melting. J. Mater. Process Tech. 241, 154-163 (2017).

96. Tian, Y., Tomus, D., Rometsch, P. \& Wu, X. H. Influences of processing parameters on surface roughness of Hastelloy $\mathrm{X}$ produced by selective laser melting. Addit. Manuf. 13, 103-112 (2017).

97. Chen, H. Y., Gu, D. D., Xiong, J. P. \& Xia, M. J. Improving additive manufacturing processability of hard-to-process overhanging structure by selective laser melting. J. Mater. Process Tech. 250, 99-108 (2017).

98. Strano, G., Hao, L., Everson, R. M. \& Evans, K. E. Surface roughness analysis in selective laser melting. In Proc. Innovative Developments on Virtual and Physical Prototyping (ed. Bartolo, P. J.) 561-565, (CRC, Boca Raton, 2012).

99. Strano, G., Hao, L., Everson, R. M. \& Evans, K. E. Surface roughness analysis, modelling and prediction in selective laser melting. J. Mater. Process Tech. 213, 589-597 (2013).
100. Qiu, C. L. et al. On the role of melt flow into the surface structure and porosity development during selective laser melting. Acta Mater. 96, 72-79 (2015).

101. Aqilah, D. N. et al. Effects of process parameters on the surface roughness of stainless steel $316 \mathrm{~L}$ parts produced by selective laser melting. J. Test. Eval. 46, 1673-1683 (2018).

102. Baciu, M. A. et al. Influence of selective laser melting processing parameters of Co-Cr-W powders on the roughness of exterior surfaces. Iop Conf. Ser.-Mat. Sci. 374, 1-5 (2018).

103. Aboulkhair, N. T., Maskery, I., Tuck, C., Ashcroft, I. \& Everitt, N. M. On the formation of A1Si10Mg single tracks and layers in selective laser melting: Microstructure and nano-mechanical properties. J. Mater. Process Tech. 230, 88-98 (2016).

104. Gu, D. D. \& Shen, Y. F. Balling phenomena in direct laser sintering of stainless steel powder: Metallurgical mechanisms and control methods. Mater. Des. 30, 2903-2910 (2009).

105. Calignano, F., Manfredi, D., Ambrosio, E. P., luliano, L. \& Fino, P. Influence of process parameters on surface roughness of aluminum parts produced by DMLS. Int J. Adv. Manuf. Tech. 67, 2743-2751 (2013).

106. Kruth, J. P. et al. Selective laser melting of iron-based powder. J. Mater. Process Tech. 149, 616-622 (2004).

107. Jamshidinia, M. \& Kovacevic, R. The influence of heat accumulation on the surface roughness in powder-bed additive manufacturing. Surf. Topogr.-Metrol. 3, 1-10 (2015).

108. Yadroitsev, I., Bertrand, P. \& Smurov, I. Parametric analysis of the selective laser melting process. Appl Surf. Sci. 253, 8064-8069 (2007).

109. Yadroitsev, I., Thivillon, L., Bertrand, P. \& Smurov, I. Strategy of manufacturing components with designed internal structure by selective laser melting of metallic powder. Appl Surf. Sci. 254, 980-983 (2007).

110. Zuo, Y., Wang, H. T. \& Xiong, J. P. The aspect ratio of surface grooves and metastable pitting of stainless steel. Corros. Sci. 44, 25-35 (2002).

111. Shahryari, A., Kamal, W. \& Omanovic, S. The effect of surface roughness on the efficiency of the cyclic potentiodynamic passivation (CPP) method in the improvement of general and pitting corrosion resistance of 316LVM stainless steel. Mater. Lett. 62, 3906-3909 (2008).

112. Kong, D. et al. Surface monitoring for pitting evolution into uniform corrosion on Cu-Ni-Zn ternary alloy in alkaline chloride solution: ex-situ LCM and in-situ SECM. Appl. Surf. Sci. 440, 245-257 (2018).

113. Kong, D. et al. Insight into the mechanism of alloying elements ( $\mathrm{Sn}, \mathrm{Be}$ ) effect on copper corrosion during long-term degradation in harsh marine environment. Appl. Surf. Sci. 455, 543-553 (2018)

114. Walter, R. \& Kannan, M. B. Influence of surface roughness on the corrosion behaviour of magnesium alloy. Mater. Des. 32, 2350-2354 (2011).

115. Leon, A. \& Aghion, E. Effect of surface roughness on corrosion fatigue performance of AlSi10Mg alloy produced by Selective Laser Melting (SLM). Mater. Charact. 131, 188-194 (2017)

116. Wang, L. Z., Wang, S. \& Wu, J. J. Experimental investigation on densification behavior and surface roughness of AlSi10Mg powders produced by selective laser melting. Opt. Laser Tech. 96, 88-96 (2017).

117. Zhang, Y., Liu, F., Chen, J. \& Yuan, Y. Effects of surface quality on corrosion resistance of $316 \mathrm{~L}$ stainless steel parts manufactured via SLM. J. Laser Appl. 29, 022306 (2017)

118. Nandwana, P. et al. Powder bed binder jet 3D printing of Inconel 718: densification, microstructural evolution and challenges. Curr. Opin. Solid Stat. Mater. Sci. 21, 207-218 (2017)

119. Zhao, $\mathrm{X}$. et al. Comparison of the microstructures and mechanical properties of Ti-6Al-4V fabricated by selective laser melting and electron beam melting. Mater. Des. 95, 21-31 (2016).

120. Chen, S. Y. et al. Microstructure and mechanical properties of open-cell porous Ti-6Al-4V fabricated by selective laser melting. J. Alloy Compd. 713, 248-254 (2017).

121. Kok, Y. et al. Anisotropy and heterogeneity of microstructure and mechanical properties in metal additive manufacturing: A critical review. Mater. Des. 139, 565-586 (2018).

122. Wu, M. W., Lai, P. H. \& Chen, J. K. Anisotropy in the impact toughness of selective laser melted Ti-6Al-4V alloy. Mat. Sci. Eng. a-Struct. 650, 295-299 (2016).

123. Awd, M. et al. Microstructural characterization of the anisotropy and cyclic deformation behavior of selective laser melted AlSi10Mg Structures. MetalsBasel 8, 825-838 (2018)

124. Dadbakhsh, S., Vrancken, B., Kruth, J. P., Luyten, J. \& Van Humbeeck, J. Texture and anisotropy in selective laser melting of NiTi alloy. Mat. Sci. Eng. a-Struct. 650, 225-232 (2016).

125. Kunze, K., Etter, T., Grasslin, J. \& Shklover, V. Texture, anisotropy in microstructure and mechanical properties of IN738LC alloy processed by selective laser melting (SLM). Mat. Sci. Eng. a-Struct. 620, 213-222 (2015). 
126. Kong, D. et al. Anisotropy in the microstructure and mechanical property for the bulk and porous $316 \mathrm{~L}$ stainless steel fabricated via selective laser melting. Mater. Lett. 235, 1-5 (2019).

127. Chen, Y. et al. Distinction of corrosion resistance of selective laser melted Al-12Si alloy on different planes. J. Alloy Compd. 747, 648-658 (2018).

128. Lou, X., Othon, M. A. \& Rebak, R. B. Corrosion fatigue crack growth of laser additively-manufactured $316 \mathrm{~L}$ stainless steel in high temperature water. Corros. Sci. 127, 120-130 (2017)

129. Chen, X. H., Li, J., Cheng, X., Wang, H. M. \& Huang, Z. Effect of heat treatment on microstructure, mechanical and corrosion properties of austenitic stainless stee 316L using arc additive manufacturing. Mat. Sci. Eng. a-Struct. 715, 307-314 (2018).

130. Huang, B., Zhai, Y. T., Liu, S. J. \& Mao, X. D. Microstructure anisotropy and its effect on mechanical properties of reduced activation ferritic/martensitic steel fabricated by selective laser melting. J. Nucl. Mater. 500, 33-41 (2018).

131. Lee, H. W., Jung, K. H., Hwang, S. K., Kang, S. H. \& Kim, D. K. Microstructure and mechanical anisotropy of CoCrW alloy processed by selective laser melting. Mat. Sci. Eng. a-Struct. 749, 65-73 (2019).

132. Dai, N., Zhang, L. -C., Zhang, J., Chen, Q. \& Wu, M. Corrosion behavior of selective laser melted Ti-6Al-4 V alloy in $\mathrm{NaCl}$ solution. Corros. Sci. 102, 484-489 (2016).

133. Zhang, $\mathrm{H}$. et al. Anisotropic corrosion resistance of TiC reinforced Ni-based composites fabricated by selective laser melting. J. Mater. Sci. Tech. 35, 1128-1136 (2019).

134. Hedberg, Y. S., Qian, B., Shen, Z. J., Virtanen, S. \& Wallinder, I. O. In vitro biocompatibility of CoCrMo dental alloys fabricated by selective laser melting Dent. Mater. 30, 525-534 (2014).

135. Kim, H. R. et al. Comparison of in vitro biocompatibility of a $\mathrm{Co}-\mathrm{Cr}$ dental alloy produced by new milling/post-sintering or traditional casting technique. Mater. Lett. 178, 300-303 (2016).

136. Majumdar, T., Eisenstein, N., Frith, J. E., Cox, S. C. \& Birbilis, N. Additive manufacturing of titanium alloys for orthopedic applications: a materials science viewpoint. Adv. Eng. Mater. 20, 1-28 (2018).

137. Liu, S. Y. \& Shin, Y. C. Additive manufacturing of Ti6Al4V alloy: A review. Mater Design 164, 1-28 (2019).

138. Low, K. H., Leong, K. F. \& Sun, C. N. Review of selective laser melting process parameters for commercially pure titanium and Ti6Al4V. In High Value Manufacturing: Advanced Research in Virtual and Rapid Prototyping. 71-76 (Leiria, Portugal, 2014)

139. Zhang, L. C. \& Attar, H. Selective laser melting of ti.tanium alloys and titanium matrix composites for biomedical applications: a review. Adv. Eng. Mater. 18 463-475 (2016).

140. Zhang, L. C., Attar, H., Calin, M. \& Eckert, J. Review on manufacture by selective laser melting and properties of titanium based materials for biomedical applications. Mater. Technol. 31, 66-76 (2016).

141. Chiu, T. M. et al. Corrosion assessment of Ti-6Al-4V fabricated using lase powder-bed fusion additive manufacturing. Electro. Acta 279, 143-151 (2018).

142. Dehoff, R. et al. Case study: additive manufacturing of aerospace brackets. Adv. Mater. Process 171, 19-22 (2013).

143. Yang, Y. et al. Crystallographic features of alpha variants and beta phase for Ti6Al-4V alloy fabricated by selective laser melting. Mat. Sci. Eng. a-Struct. 707, 548-558 (2017)

144. Chen, J. -R. \& Tsai, W. -T. In situ corrosion monitoring of Ti-6Al-4V alloy in $\mathrm{H} 2 \mathrm{SO} 4 / \mathrm{HCl}$ mixed solution using electrochemical AFM. Electro. Acta 56, 1746-1751 (2011)

145. Toptan, F. et al. Corrosion and tribocorrosion behaviour of Ti6Al4V produced by selective laser melting and hot pressing in comparison with the commercial alloy. J. Mater. Process Tech. 266, 239-245 (2019).

146. Liang, Z. L., Sun, Z. G., Zhang, W. S., Wu, S. K. \& Chang, H. The effect of heat treatment on microstructure evolution and tensile properties of selective laser melted Ti6Al4V alloy. J. Alloy Compd. 782, 1041-1048 (2019).

147. Yan, X. C. et al. Effect of heat treatment on the phase transformation and mechanical properties of Ti6Al4V fabricated by selective laser melting. J. Alloy Compd. 764, 1056-1071 (2018).

148. Wauthle, R. et al. Effects of build orientation and heat treatment on the microstructure and mechanical properties of selective laser melted Ti6Al4V lattice structures. Addit. Manuf. 5, 77-84 (2015).

149. Vrancken, B., Thijs, L., Kruth, J. P. \& Van Humbeeck, J. Heat treatment of Ti6Al4V produced by Selective Laser Melting: Microstructure and mechanical properties. J. Alloy Compd. 541, 177-185 (2012).

150. Dai, N. W., Zhang, J. X., Chen, Y. \& Zhang, L. C. Heat treatment degrading the corrosion resistance of selective laser melted Ti-6Al-4V alloy. J. Electrochem Soc 164, C428-C434 (2017).

151. Zhang, L. C., Klemm, D., Eckert, J., Hao, Y. L. \& Sercombe, T. B. Manufacture by selective laser melting and mechanical behavior of a biomedical Ti-24Nb-4Zr8Sn alloy. Scr. Mater. 65, 21-24 (2011).
152. Yang, C. L. et al. Simultaneous improvement in strength and plasticity of Ti$24 \mathrm{Nb}-4 \mathrm{Zr}-8 \mathrm{Sn}$ manufactured by selective laser melting. Mater. Des. 157, 52-59 (2018).

153. Liu, C. F., Li, S. J., Hou, W. T., Hao, Y. L. \& Huang, H. H. Enhancing corrosion resistance and biocompatibility of interconnected porous beta-type Ti-24Nb$4 \mathrm{Zr}-8 \mathrm{Sn}$ alloy scaffold through alkaline treatment and type I collagen immobilization. Appl Surf. Sci. 476, 325-334 (2019).

154. Ren, H. S., Tian, X. J., Liu, D., Liu, J. \& Wang, H. M. Microstructural evolution and mechanical properties of laser melting deposited Ti-6.5Al-3.5Mo-1.5Zr-0.3S titanium alloy. Trans. Nonfer Met. Soc. China 25, 1856-1864 (2015).

155. Zong, X. et al. High strain rate response of Ti-6.5Al-3.5Mo-1.5Zr-0.3Si titanium alloy fabricated by laser additive manufacturing. J. Alloy Compd. 781, 47-55 (2019).

156. Ahuja, B., Karg, M., Nagulin, K. Y. \& Schmidt, M. Fabrication and characterization of high strength Al-Cu alloys processed using laser beam melting in metal powder bed. Phys. Procedia. 56, 135-146 (2014).

157. Gu, T., Chen, B., Tan, C. W. \& Feng, J. C. Microstructure evolution and mechanical properties of laser additive manufacturing of high strength Al-Cu-Mg alloy. Opt. Laser Technol. 112, 140-150 (2019).

158. Wang, P. et al. Microstructure and mechanical properties of a heat-treatable Al3.5Cu-1.5Mg-1Si alloy produced by selective laser melting. Mat. Sci. Eng. a-Struct. 711, 562-570 (2018).

159. Montero-Sistiaga, M. L. et al. Changing the alloy composition of Al7075 for better processability by selective laser melting. J. Mater. Process Tech. 238, 437-445 (2016).

160. Suryawanshi, J. et al. Simultaneous enhancements of strength and toughness in an Al-12Si alloy synthesized using selective laser melting. Acta Mater. 115, 285-294 (2016).

161. Siddique, S., Imran, M., Wycisk, E., Emmelmann, C. \& Walther, F. Influence of process-induced microstructure and imperfections on mechanical properties of AlSi12 processed by selective laser melting. J. Mater. Process Tech. 221, 205-213 (2015).

162. Rashid, R. A. R., Ali, H., Palanisamy, S. \& Masood, S. H. Effect of process parameters on the surface characteristics of AlSi12 samples made via selective laser melting. Mater. Today-Proc. 4, 8724-8730 (2017).

163. Rashid, R. et al. Effect of energy per layer on the anisotropy of selective laser melted AISi12 aluminium alloy. Addit. Manuf. 22, 426-439 (2018).

164. Aboulkhair, N. T., Maskery, I., Tuck, C., Ashcroft, I. \& Everitt, N. M. On the formation of AlSi10Mg single tracks and layers in selective laser melting: microstructure and nano-mechanical properties. J. Mater. Process Tech. 230, 88-98 (2016).

165. Kang, N. et al. Microstructure and wear behavior of in-situ hypereutectic Al-high Si alloys produced by selective laser melting. Mater. Des. 99, 120-126 (2016).

166. Maskery, I. et al. Quantification and characterisation of porosity in selectively laser melted Al-Si10-Mg using X-ray computed tomography. Mater. Charact. 111, 193-204 (2016).

167. Cabrini, M. et al. Evaluation of corrosion resistance of $\mathrm{Al}-10 \mathrm{Si}-\mathrm{Mg}$ alloy obtained by means of direct metal laser sintering. J. Mater. Process Tech. 231, 326-335 (2016).

168. Cabrini, M. et al. Corrosion resistance of direct metal laser sintering AISiMg alloy. Surf. Inter. Anal. 48, 818-826 (2016).

169. Cabrini, M. et al. Corrosion resistance in chloride solution of the AlSi10Mg alloy obtained by means of LPBF. Surf. Inter. Anal. 48, 818-826 (2018).

170. Liu, X. H., Zhao, C. C., Zhou, X., Shen, Z. J. \& Liu, W. Microstructure of selective laser melted AlSi10Mg alloy. Mater. Design 168, 1-9 (2019).

171. Liu, Y. J. et al. Gradient in microstructure and mechanical property of selective laser melted AlSi10Mg. J. Alloy Compd. 735, 1414-1421 (2018).

172. Wu, J., Wang, X. Q., Wang, W., Attallah, M. M. \& Loretto, M. H. Microstructure and strength of selectively laser melted AISi10Mg. Acta Mater. 117, 311-320 (2016).

173. Prashanth, K. G. et al. Microstructure and mechanical properties of Al-12Si produced by selective laser melting: effect of heat treatment. Mat. Sci. Eng. aStruct. 590, 153-160 (2014).

174. Revilla, R. I. \& De Graeve, I. Influence of Si content on the microstructure and corrosion behavior of additive manufactured Al-Si alloys. J. Electrochem Soc. 165, C926-C932 (2018)

175. Zakay, A. \& Aghion, E. Effect of post-heat treatment on the corrosion behavior of AlSi10Mg alloy produced by additive manufacturing. Jom 71, 1150-1157 (2019).

176. Gharbi, O. et al. On the corrosion of additively manufactured aluminium alloy AA2024 prepared by selective laser melting. Corros. Sci. 143, 93-106 (2018).

177. Jerrard, P. G. E., Hao, L. \& Evans, K. E. Experimental investigation into selective laser melting of austenitic and martensitic stainless steel powder mixtures. $P$ / Mech. Eng. B-J. Eng. 223, 1409-1416 (2009).

178. Abd-Elghany, K. \& Bourell, D. L. Property evaluation of $304 \mathrm{~L}$ stainless steel fabricated by selective laser melting. Rapid Prototyp. J. 18, 420-428 (2012) 
179. Krishnan, S. et al. Effect of crystallographic orientation on the pitting corrosion resistance of laser surface melted AISI 304L austenitic stainless steel. J. Commun. 1, 71-87 (2013).

180. Lei, J. B. et al. Comparative study on microstructure and corrosion performance of 316 stainless steel prepared by laser melting deposition with ring-shaped beam and Gaussian beam. Opt. Laser Technol. 111, 271-283 (2019).

181. Xu, X. et al. Morphologies, microstructures, and mechanical properties of samples produced using laser metal deposition with $316 \mathrm{~L}$ stainless steel wire. Opt. Laser Eng. 94, 1-11 (2017).

182. Yakout, M., Elbestawi, M. A. \& Veldhuis, S. C. Density and mechanical properties in selective laser melting of Invar 36 and stainless steel 316L. J. Mater. Process Tech. 266, 397-420 (2019).

183. Salman, O. O., Gammer, C., Chaubey, A. K., Eckert, J. \& Scudino, S. Effect of heat treatment on microstructure and mechanical properties of $316 \mathrm{~L}$ steel synthesized by selective laser melting. Mat. Sci. Eng. a-Struct. 748, 205-212 (2019).

184. Ni, X. Q. et al. Anisotropy in mechanical properties and corrosion resistance of $316 \mathrm{~L}$ stainless steel fabricated by selective laser melting. Int J. Min. Met. Mater. 26, 319-328 (2019).

185. Alsalla, H. H., Smith, C. \& Hao, L. Effect of build orientation on the surface quality, microstructure and mechanical properties of selective laser melting $316 \mathrm{~L}$ stainless steel. Rapid Prototyp. J. 24, 9-17 (2018).

186. Chao, Q. et al. On the enhanced corrosion resistance of a selective laser melted austenitic stainless steel. Scr. Mater. 141, 94-98 (2017).

187. Rottger, A., Geenen, K., Windmann, M., Binner, F. \& Theisen, W. Comparison of microstructure and mechanical properties of $316 \mathrm{~L}$ austenitic steel processed by selective laser melting with hot-isostatic pressed and cast material. Mat. Sci. Eng. a-Struct. 678, 365-376 (2016).

188. Kurzynowski, T., Gruber, K., Stopyra, W., Kuznicka, B. \& Chlebus, E. Correlation between process parameters, microstructure and properties of $316 \mathrm{~L}$ stainless steel processed by selective laser melting. Mat. Sci. Eng. a-Struct. 718, 64-73 (2018)

189. Stewart, J.\& Williams, D. E. The Initiation of pitting corrosion on austenitic stainless steel: on the role and importance of sulfide inclusions. Corros. Sci. 33, 457-463 (1992).

190. Schaller, R. F. et al. The role of microstructure and surface finish on the corrosion of selective laser melted 304L. J. Electrochem Soc. 165, C234-C242 (2018).

191. Zheng, S. Q., Li, C. Y., Qi, Y. M., Chen, L. Q. \& Chen, C. F. Mechanism of (Mg,Al, Ca)-oxide inclusion-induced pitting corrosion in $316 \mathrm{~L}$ stainless steel exposed to sulphur environments containing chloride ion. Corros. Sci. 67, 20-31 (2013).

192. Man, C. et al. The effect of sub-grain structure on intergranular corrosion of $316 \mathrm{~L}$ stainless steel fabricated via selective laser melting. Mater. Lett. 243, 157-160 (2019)

193. Lou, X., Song, M., Emigh, P. W., Othon, M. A. \& Andresen, P. L. On the stress corrosion crack growth behaviour in high temperature water of $316 \mathrm{~L}$ stainless steel made by laser powder bed fusion additive manufacturing. Corros. Sci. 128, 140-153 (2017).

194. Lou, X., Andresen, P. L. \& Rebak, R. B. Oxide inclusions in laser additive manufactured stainless steel and their effects on impact toughness and stress corrosion cracking behavior. J. Nucl. Mater. 499, 182-190 (2018).
195. Sutton, A. T., Kriewall, C. S., Leu, M. C. \& Newkirk, J. W. Powder characterisation techniques and effects of powder characteristics on part properties in powderbed fusion processes. Virtu. Phys. Prototyp. 12, 3-29 (2016).

196. Strondl, A., Lyckfeldt, O., Brodin, H. \& Ackelid, U. Characterization and control of powder properties for additive manufacturing. JOM 67, 549-554 (2015).

197. Galati, M., Luliano, L., Salmi, A. \& Atzeni, E. Modelling energy source and powder properties for the development of a thermal FE model of the EBM additive manufacturing process. Addit. Manuf. 14, 49-59 (2017).

198. Slotwinski, J. A. \& Garboczi, E. J. Metrology needs for metal additive manufacturing powders. JOM 67, 538-543 (2015).

199. Chen, G. et al. A comparative study of Ti-6Al-4V powders for additive manufacturing by gas atomization, plasma rotating electrode process and plasma atomization. Powder Tech. 333, 38-46 (2018).

200. Lass, E. A., Stoudt, M. R. \& Williams, M. E. Additively manufactured nitrogenatomized 17-4 $\mathrm{PH}$ stainless steel with mechanical properties comparable to wrought. Met. Mater. Trans. A 50a, 1619-1624 (2019).

201. Zambon, A. Nitrogen versus helium: effects of the choice of the atomizing gas on the structures of Fe50Ni30Si10B10 and Fe32Ni36Ta7Si8B17 powders. Mat. Sci. Eng. a-Struct. 375, 630-637 (2004).

202. Aksoy, A. \& Unal, R. Effects of gas pressure and protrusion length of melt delivery tube on powder size and powder morphology of nitrogen gas atomised tin powders. Powder Met. 49, 349-354 (2006).

203. Cabrini, M. et al. Effect of heat treatment on corrosion resistance of DMLS AlSi10Mg alloy. Electro. Acta 206, 346-355 (2016).

204. Revilla, R. I., Liang, J., Godet, S. \& De Graeve, I. Local corrosion behavior of additive manufactured AISiMg alloy assessed by SEM and SKPFM. J. Electrochem. Soc. 164, C27-C35 (2017)

205. Tang, M. \& Pistorius, P. C. Anisotropic mechanical behavior of AlSi10Mg parts produced by selective laser melting. JOM 69, 516-522 (2017).

206. Rubben, T., Revilla, R. I. \& De Graeve, I. Influence of heat treatments on the corrosion mechanism of additive manufactured AlSi10Mg. Corros. Sci. 147, 406-415 (2019).

207. Wang, X. Y. \& Li, D. Y. Mechanical and electrochemical behavior of nanocrystalline surface of 304 stainless steel. Electro. Acta 47, 3939-3947 (2002).

(i) Open Access This article is licensed under a Creative Commons Attribution 4.0 International License, which permits use, sharing, adaptation, distribution and reproduction in any medium or format, as long as you give appropriate credit to the original author(s) and the source, provide a link to the Creative Commons license, and indicate if changes were made. The images or other third party material in this article are included in the article's Creative Commons license, unless indicated otherwise in a credit line to the material. If material is not included in the article's Creative Commons license and your intended use is not permitted by statutory regulation or exceeds the permitted use, you will need to obtain permission directly from the copyright holder. To view a copy of this license, visit http://creativecommons. org/licenses/by/4.0/.

(c) The Author(s) 2019 